\title{
A Preliminary Report on the
}

\section{Pollen and Spores}

of the Pre-Selma Upper

Cretaceous Strata of

\section{Western Alabama}

By ESTELLA B. LEOPOLD and HELEN M. PAKISER

STUDIES OF PRE-SELMA CRETACEOUS CORE SAMPLES

FROM THE OUTCROP AREA IN WESTERN ALABAMA

GE OL O G C A L S U R E Y B U L LE T I N 1160-E

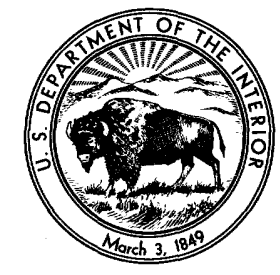





\section{CONTENTS}

Page

Abstract._._.

Introduction.

Source of material and methods used

Composition of the microfossil assemblage and affinities with modern plants

Family Hystrichosphaerideae

Class Dinoflagellata

Order Chroococcales_._._._._._._._. 80

Order Lycopodiaceae.... 80

Class Filicinae..._._._. 80

Class Gymnospermae.

Class Angiospermae

Palynomorph zones of the pre-Selma strata

Facies changes

Floristic zones._._.

Stratigraphic interpretation and age of the floras _. 90

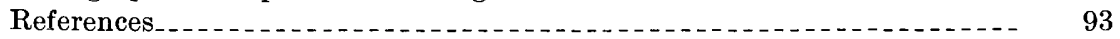

\section{ILLUSTRATIONS}

[Plates 3-9 follow index]

Plate 3. Fern and lower plant spores of the Tuscaloosa Group.

4. Gymnosperm pollen of the Tuscaloosa Group.

5. Dicotyledonous pollen of the Tuscaloosa Group.

6. Spores, gymnosperm pollen and pteridosperm pollen of the McShan and Eutaw Formations.

7. Gymnosperm and monocotyledonous pollen of the McShan and Eutaw Formations.

8. Dicotyledonous pollen of the MeShan and Eutaw Formations.

9. Microforaminifers, Dinoflagellate algae and Hystrichosphaerideae of the McShan and Eutaw Formations.

\section{TABLES}

TABLE 14. Source and type of samples studied for contained pollen, spores,

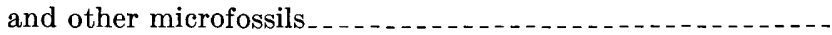

15. Microfossils identified in core samples of pre-Selma Upper Cretaceous sediments in western Alabama..............

16. Dicotyledonous families represented by pollen in pre-Selma

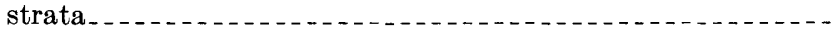

17. List of palynomorphs of restricted distribution within the pre-

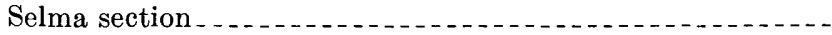

18. Comparative percentages of dicot pollen within pollen and spore tallies of the Potomac group of Maryland and Delaware, (Groot and Penny, 1960) and pre-Selma Cretaceous

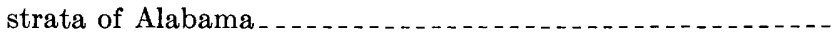





\title{
STUDIES OF PRE-SELMA CRETACEOUS CORE SAMPLES FROM THE OUTCROP AREA IN WESTERN ALABAMA
}

\section{E. A PRELIMINARY REPORT ON THE POLLEN AND SPORES OF THE PRE-SELMA UPPER GRETAGEOUS STRATA OF WESTERN ALABAMA}

\author{
By Estella B. Leopold and Helen M. Pakiser
}

\begin{abstract}
In a preliminary study of the pre-Selma Upper Cretaceous strata the authors report a diverse assemblage of fossil pollen and spores representing a primarily dicotyledonous flora. Two of the vascular plant families represented are now restricted to subtropical areas and one of them is now limited to the southern hemisphere.

Remains of planktonic algae and abundant microforaminifers in the Eutaw and McShan formations suggest that these sediments accumulated in marine waters, probably somewhat below the turbulent wave zone.

The depositional environment of the Coker formation, as inferred from pollen in several lignite seams, was probably shallow water and lagoonal. Pollen and spores that are most abundant in this lignite and in the associated siltstone may be assumed to have been derived locally, and probably represent shore or lagoonmargin vegetation. The modern families to which these pollen are related-for example, the holly, myrtle, tea, and cyrilla families-have representatives that occupy swampy-bay or lagoon-margin habitats in subtropical areas. The land plant assemblage of the Coker formation is only slightly different from that of the overlying lower part of the Gordo formation. The middle part of the Gordo was not sampled and the upper part of the formation was unpolleniferous, so nothing can be inferred from pollen about the depositional environment of the uppermost part of the Tuscaloosa group.

Where affinities with modern vascular plant families can be recognized, pollen and spore identifications to a certain extent corroborate taxa of plant megafossils identified by earlier workers from these strata; but this corroboration is mainly on the family, not the generic level.

Comparison with Cretaceous pollen and spore floras of central and northern Europe supports a Late Cretaceous age for the Alabama pollen flora; a close similarity with Cenomanian and Turonian pollen floras of Germany indicates an early Late Cretaceous age.
\end{abstract}

\section{INTRODUCTION}

The present study is a listing of pollen, spores, and certain other microfossils found in well-core sediments of the Tuscaloosa group and the Eutaw and McShan formations (Monroe, 1955; also see chapter A by Monroe in this bulletin). This report should be considered a 
preliminary contribution, for it is clear from the megafossil remains (Berry, 1919) and from the present evidence that the flora of these strata is an enormously rich and diversified one. The fact that there exist at least 105 species among the 2,000 specimens examined for the present report clearly demonstrates this floristic diversity.

The presently available taxonomic literature concerning microspores and pollen of upper Mesozoic strata is almost entirely based on European material. In the identification of the Alabama material, we compared our specimens with the type figure and descriptions for the species or genera determined. All references utilized in the identifications are included in the bibliography. Though we have encountered many new species and one genus that do not seem to have been named to date, we shall undertake formal description of these at a later date, and for the present report shall refer to the new forms as "confer" (cf. or compare) with their most nearly related species.

\section{SOURCE OF MATERIAL AND METHODS USED}

Twenty-nine samples of sediments from the Tuscaloosa group and the McShan and Eutaw formations were taken from three cores (table 14), and were studied for contained pollen, spores, and other microfossils. The locations of these three core holes are shown on the index map of plate 1 ; the lithologic composition of the core sediments was diagrammed by Bergenback on plate 1 and the positions of the samples analyzed for pollen and spores are shown to the extreme right of the lithologic section of each core. The segments of core utilized in the pollen and spore study are listed according to depth and lithotype in table 14.

The polleniferous material of the Tuscaloosa group includes three groups of samples, one from each of the two cores of the Eoline member of the Coker formation, and one from the Gordo formation. The unnamed upper member of the Coker formation was sampled (Webb hole, 212.2-214.9 feet depth and Boykin hole, 204.2-206.3 feet depth-depth intervals from Monroe, 1955) near its base but these sediments contained no plant fossils; the general mottled pink and yellow color of the unit suggests an oxidation state that makes it an unlikely source for fossil pollen and spores. The only sample obtained from the Gordo formation containing plant fossils is from a gray clay unit in the lower part of the formation, near the top of the Boykin hole. Samples from the main part of the Gordo formation were not available because the bulk of the unit was not cored, but two samples (lower part of Crawford hole, 399.1-420.8 feet depth) of sandy clay from near the top of the formation were prepared and found to be unfossiliferous. 
TABLE 14.- Source and type of samples studied for contained pollen, spores, and other microfossils

\begin{tabular}{c|c|c|c|c}
$\begin{array}{c}\text { USGS } \\
\text { paleobotany loc. }\end{array}$ & Formation & Sample & Lithotype & $\begin{array}{c}\text { Depth } \\
\text { intervals } \\
\text { sampled } \\
\text { (feet) }\end{array}$ \\
\hline
\end{tabular}

Core from Crawford hole, sec. 15, T. 18 N., R. 8 E., Perry County

\begin{tabular}{|c|c|c|c|c|}
\hline D1110 & $\begin{array}{l}\text { Eutaw } \\
\text { do }\end{array}$ & $\begin{array}{l}1 \\
2 \\
3\end{array}$ & $\begin{array}{l}\text { Siltstone } \\
\text { Claystone }\end{array}$ & $\begin{array}{l}111.2-118.4 \\
129.1-131.3 \\
136.0-139.6\end{array}$ \\
\hline \multirow[t]{2}{*}{ D1456 } & $\begin{array}{l}\text { MeShan } \\
- \text { do }\end{array}$ & $\begin{array}{l}4 \\
5 \\
6\end{array}$ & - & $\begin{array}{l}186.5-192.5 \\
296.5-302.3 \\
314.5-316.6\end{array}$ \\
\hline & Gordo & $\begin{array}{l}7 \\
8\end{array}$ & 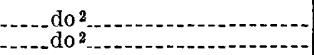 & $\begin{array}{l}399.1-402.1 \\
410.1-420.8\end{array}$ \\
\hline
\end{tabular}

Core from Boykin hole, sec. 5, T. 24 N., R. 4 E., Tuscaloosa County

\begin{tabular}{|c|c|c|c|c|}
\hline D1457_. & Gordo_-n_. & 1 & Sandy siltstone....-. & $10.5-20.6$ \\
\hline \multirow[t]{2}{*}{ D1111_. } & Coker, upper member & $\begin{array}{l}2 \\
3\end{array}$ & Lignite $^{2}-\ldots$ & $\begin{array}{l}204.2-206.3 \\
247.7-249.2\end{array}$ \\
\hline & Coker, Eoline member...... & $\begin{array}{r}4 \\
5 \\
6 \\
7 \\
8 \\
9 \\
10 \\
11\end{array}$ & 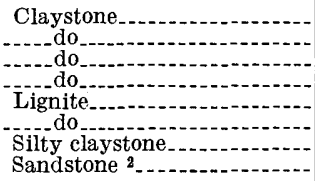 & $\begin{array}{r}\text { near } 270.5 \\
270.5-271.4 \\
314.2-324.4 \\
324.4-335.0 \\
346.4-348.5 \\
352.0-353.8 \\
378.1-385.1 \\
476.0-477.6\end{array}$ \\
\hline
\end{tabular}

Core from Webb hole, sec. 16, T. 21 N., R. 8 E., Perry County

\begin{tabular}{|c|c|c|c|c|}
\hline \multirow[t]{2}{*}{ D1109. } & Coker, upper member.-...-. & 1 & Claystone ${ }^{2}-.$. & 212.2-214. 9 \\
\hline & Coker, Eoline member.- & $\begin{array}{r}2 \\
3 \\
4 \\
5 \\
6 \\
7 \\
8 \\
9 \\
10\end{array}$ & \begin{tabular}{|l} 
Claystone \\
do do \\
Sandy claystone. \\
Claystone \\
Siltstone \\
Claystone \\
do \\
\end{tabular} & $\begin{array}{l}226.8-229.8 \\
229.8-232.6 \\
238.8-248.0 \\
248.0-261.0 \\
298.0-299.6 \\
360.0-364.0 \\
374.3-375.8 \\
427.0-430.0 \\
457.3-460.0\end{array}$ \\
\hline
\end{tabular}

1 Depth intervals from Monroe, 1955.

2 Sediment sampled contained no fossil pollen or spores.

From the Crawford core six polleniferous samples were obtainedthree from the middle and upper parts of the McShan formation, and three from the middle part of the Eutaw formation (table 14).

The Boykin hole samples of the Tuscaloosa group and the Crawford hole samples of the McShan and Eutaw formations can be considered a coarsely sampled composite pollen section of the pre-Selma strata, the largest sampling gaps being the probably unfossiliferous upper member of the Coker and the chiefly unsampled Gordo formation. The Webb hole pollen samples, which are spaced from less than 1 to 50 feet apart within the Eoline member of the Coker formation, serve as a laterally equivalent pollen sequence for comparison with the Eoline member in the Boykin hole. 
The methods by which the sediments were treated in order to isolate the pollen and spore fraction include the hydrofluoric acid technique described by Faegri and Iversen (1950, p. 62), and the heavy liquid flotation method described by Funkhouser and Evitt (1959). The fossil material was stained with Safranin "O" and mounted in glycerine jelly; after the slides were cured with low heat $\left(50^{\circ} \mathrm{C}\right)$ for a few days, the coverslips were sealed with lacquer.

The pollen and spore species are noted in table 15 according to relative abundance in the organic residues, as follows:

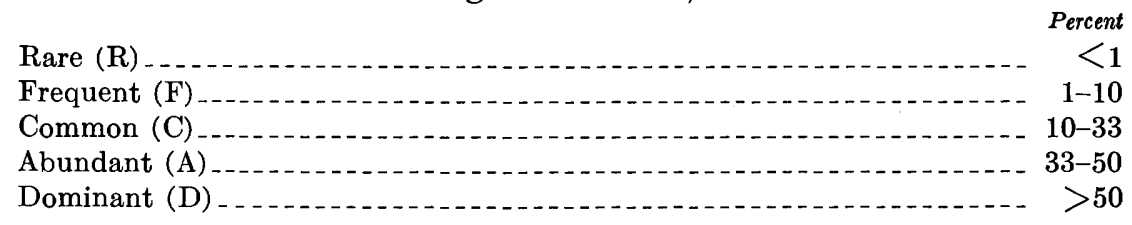

COMPOSITION OF THE MICROFOSSIL ASSEMBLAGE AND AFFINITIES WITH MODERN PLANTS

The pre-Selma Upper Cretaceous pollen and spore flora as listed in table 15 embraces a total of 105 identified species and 92 genera. Fifteen forms represent hystrichomorphs and unicellular algae, 30 species are sporae dispersae representing members of pteridophyte groups, 18 species are Gymnospermae, and 40 species are Angiospermae.

\section{FAMILY HYSTRICHOSPHAERIDEAE}

The unicellular forms placed in the Hystrichosphaerideae bear organ generic names and are of uncertain affinities. Some evidence indicates that certain hystrichomorphs are members of the Dinoflagellata (Cookson, 1956; Braarud, 1945). Hystrichomorphs may be abundant in modern marine sediments (McKee, Chronic, and Leopold, 1959), though they are occasionally found as fossils in continental deposits.

Most of the species of Hystrichosphaerideae in the present material are known from Upper Cretaceous strata of Europe. Micrhystridium inconspicuum Deflandre (1937) was described from Cenomanian sediments from the Paris Basin, but its total stratigraphic range is not known. Pterospermopsis ginginensis Deflandre and Cookson, which is now known only from marine Upper Cretaceous Senonian strata of Western Australia, is found in McShan and Eutaw sediments here (plate 9, fig. 6). The forms Micrhystridium piliferum Deflandre, Hystrichosphaeridium multifurcatum Deflandre, and Hystrichosphaera cornigera Wetzel are all common in the Silex deposits of the Paris Basin (Deflandre, 1937). Hystrichosphaeridium pulcherrimum Deflandre \& Cookson (pl. 9, fig. 13) is a Cretaceous form known primarily from Australia. The other Hystrichosphaerideae species 
TABLE 15.-Microfossils identified in core samples of pre-Selma Upper Cretaceous sediments in western Alabama

[Relative abundance in samples indicated by R, rare; F, frequent; C, common; A, abundant; and D, dominant]

\begin{tabular}{|c|c|c|c|c|c|c|c|c|c|c|c|c|c|c|c|c|c|c|c|c|c|c|c|c|c|}
\hline \multirow{4}{*}{ Species identified } & Name of core & \multicolumn{9}{|c|}{ Webb core } & \multicolumn{9}{|c|}{ Boykin core } & \multicolumn{6}{|c|}{ Crawford core } \\
\hline & USGS paleobotany locality. & \multicolumn{9}{|c|}{ D1109 } & \multicolumn{8}{|c|}{ D1111 } & D1457 & \multicolumn{3}{|c|}{ D1456 } & \multicolumn{3}{|c|}{ D1110 } \\
\hline & Formation & \multicolumn{9}{|c|}{ Coker, Eoline member } & \multicolumn{8}{|c|}{ Coker, Eoline member } & Gordo & \multicolumn{3}{|c|}{ McShan } & \multicolumn{3}{|c|}{ Eutaw } \\
\hline & Sample No_- & 10 & 9 & 8 & 7 & 6 & 5 & 4 & 3 & 2 & 10 & 9 & 8 & 7 & 6 & 5 & 4 & 3 & 1 & 6 & $\mathbf{5}$ & 4 & 3 & 2 & 1 \\
\hline \multicolumn{2}{|l|}{ Forminifera... } & & & & & & & & & & & & & & & & & & & & $\mathrm{D}$ & $\mathbf{F}$ & $\mathrm{D}$ & $\mathbf{A}$ & D \\
\hline \multirow{8}{*}{\multicolumn{2}{|c|}{ 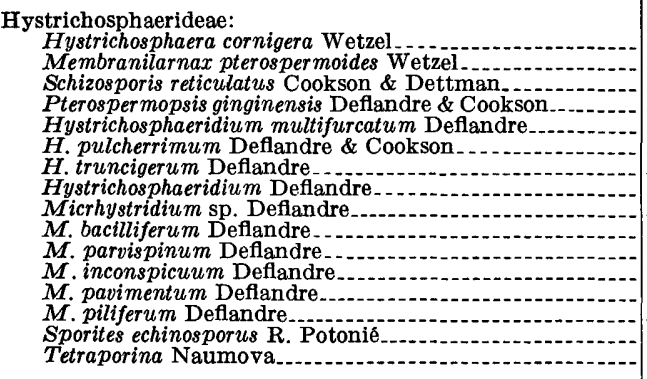 }} & & $-\cdots$ & $\mid-1$ & 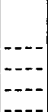 & 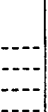 & & & $-\cdot-\cdot \mid$ & 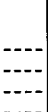 & & 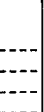 & 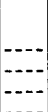 & $\mid$\begin{tabular}{l}
$\cdots$ \\
\hdashline$-\cdots$ \\
$-\cdots$
\end{tabular} & 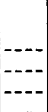 & $--\cdot$ & $--\cdot \mid$ & $\cdots$ & & & $\begin{array}{c}\mathrm{R} \\
-\mathrm{R} \\
\mathrm{C}\end{array}$ & $\begin{array}{c}\mathbf{R} \\
R\end{array}$ & 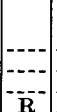 & $\mid--$ & $-\cdot-$ \\
\hline & & $\cdots$ & & $\bar{R}$ & {$\left[\begin{array}{l}--- \\
-\cdots- \\
-\cdots-\end{array}\right.$} & & $\bar{R}$ & R & & $|---|$ & $\mid$\begin{tabular}{l}
$-\cdots-$ \\
\hdashline$--\cdot$ \\
--1
\end{tabular} & --- & $\mid--\cdot$ & 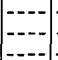 & 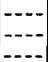 & $\mid--\bar{~}$ & {$\left[\begin{array}{l}-\cdots \\
\hdashline-\cdots \\
-\cdots\end{array}\right.$} & $\mid--\cdot$ & & $\underset{R}{R}$ & C & $\begin{array}{c}\mathbf{R} \\
\mathbf{R} \\
-\end{array}$ & $\begin{array}{c}\mathbf{R} \\
\mathbf{F}\end{array}$ & $-\cdots$ & $\begin{array}{l}\mathbf{F} \\
\mathbf{R}\end{array}$ \\
\hline & & ... & - & -... & \begin{tabular}{c}
$-\cdots$ \\
\hdashline$-\cdots$ \\
\hdashline$-\cdots$
\end{tabular} & $\begin{array}{l}-\cdots \\
-\cdots \\
-\cdots\end{array}$ & & & & 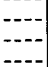 & $\begin{array}{l} \\
\cdots \\
-\end{array}$ & & & $\mid$\begin{tabular}{c}
- \\
\hdashline-- \\
\hdashline-- \\
\end{tabular} & \begin{tabular}{c}
--1 \\
\hdashline$-\cdots$ \\
\hdashline$-\cdots$
\end{tabular} & $\mathbf{R}$ & - & 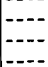 & & $\mathrm{R}$ & ב.:- & R & $\mathrm{F}$ & $\begin{array}{c}\mathbf{R} \\
\mathbf{C} \\
-\end{array}$ & $\mathrm{F}$ \\
\hline & & $\cdots$ & $-\cdots$ & $-\cdots$ & $-\cdots$ & $\begin{array}{l}\cdots-- \\
\cdots-\cdots\end{array}$ & - n n & $-\cdots$ & - n & $-\cdots$ & 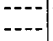 & $-\cdots$ & $-\cdots$ & $|---|$ & $-\cdots$ & $-\cdots$ & $(---$ & $-\cdots$ & & & 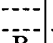 & & --- & $-\cdots$ & $\mathbf{R}$ \\
\hline & & - & $-\cdots$ & $-\cdots$ & 沗 & --- & - n & $-\cdots$ & {$[--$} & $-\cdots$ & - & $\begin{array}{l}-\cdots \\
-\cdots-\end{array}$ & $-\cdots$ & $-\cdots$ & $\mathbf{R}$ & $-\cdots$ & $-\cdots$ & $-\cdots$ & & $\mathbf{R}$ & $\begin{array}{c}\mathrm{R} \\
-\end{array}$ & $\begin{array}{l}\mathbf{R} \\
\mathbf{R}\end{array}$ & $\mid---$ & $-\cdots$ & $-\cdots$ \\
\hline & & & $-\cdots$ & -- & $-\cdots$ & & P & -- & $-\cdots$ & -- & $-\cdots$ & & --- & $-\cdots$ & $-\cdots$ & $\cdots$ & --- & $-\cdots$ & & & ( n & $\mathbf{R}$ & $-\cdots$ & $-\cdots$ & $\cdots$ \\
\hline & & 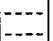 & $\cdots-$ & n... & $-\cdots$ & -..- & $\mathbf{R}$ & $-\cdots$ & --- & --- & - & $\cdots$ & $-\cdots-$ & $|--|$ & $-\cdots$ & $--\cdot$ & $-\cdots$ & 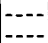 & & $-\bar{R}$ & -..- & 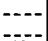 & $\mid---$ & $\mathbf{R}$ & $--\cdot$ \\
\hline & & $-\cdots$ & $-\cdots$ & $-\cdots$ & -- & -- & & $\cdots$ & & $-\cdots$ & $-\cdots$ & --- & & $-\cdots$ & & $-\cdots$ & $-\cdots$ & - & & $\ldots$ & -- & $\mathrm{R}$ & -- & - & (n) \\
\hline \multicolumn{2}{|l|}{$\begin{array}{l}\text { Dinoflagellata: } \\
\text { Undetermine }\end{array}$} & & & & & & & & & & & & & $\mathbf{R}$ & & & & | & & $\mathbf{R}$ & & & & $\mathbf{R}$ & \\
\hline \multirow{2}{*}{\multicolumn{2}{|c|}{$\begin{array}{l}\text { Deflandrea bakeri f. pellucida Deflandre \& Cookson } \\
\text { Gonyaulax transparens Sarjeant } \\
\text { Paleohystrichosphora Deflandre. }\end{array}$}} & -- & --- & -- & -- & . & & $-\cdots$ & $-\cdots$ & --- & - & --- & $-\cdots$ & $-\cdots$ & $-\cdots$ & - &.-- & $\cdots$ & & $-\cdots$ & $\cdots$ & --- & $-\cdots$ & 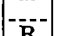 & $\mathbf{R}$ \\
\hline & & - & - & $-\cdots$ & $-\cdots$ & $\ldots$ & & $\mid---$ & $\mid--$ & ( & 烈 & & $\ldots$ & (n) & $-\cdots$ & & & $\begin{array}{l}--- \\
---\end{array}$ & & (n... & ( & & $\mathrm{R}$ & $\begin{array}{c}\mathbf{n} \\
---\end{array}$ & $\cdots$ \\
\hline ef. Wetzeliella glabn & Cook & & --- & $-\cdots$ & $-\cdots$ & - & $-\ldots$ & $-\cdots$ & $\cdots$ & - & {$[\cdots$} & $\mathbf{R}$ & $-\cdots$ & - & $-\cdots$ & ..... & $\cdots$ & $-\cdots$ & & $-\cdots$ & F & $\mathbf{R}$ & $\mathbf{R}$ & $\mathbf{F}$ & $-\cdots$ \\
\hline \multicolumn{2}{|l|}{$\begin{array}{l}\text { hroococcales: } \\
\text { cf. Aphanoth }\end{array}$} & & & & & & & & & & & & & & & & & -- & & & $\mathbf{R}$ & & $\mid--$. & & |--- \\
\hline \multirow{2}{*}{\multicolumn{2}{|c|}{$\begin{array}{l}\text { Sporae Dispersae: } \\
\text { Baculatisporites primarius (Wolff) Thomson and Pflug. } \\
\text { Cicatricosisporites brevilaesuratus Couper. } \\
\text { C. dorogensis } \mathrm{R} \text {. Potonié and Gelletich } \\
\text { C. dunrobensis Couper. }\end{array}$}} & & & & & & & & . & & & & & & . & & & & & & $\mathbf{R}$ & & & $\cdots$ & $\cdots$ \\
\hline & & $\mathbf{F}$ & $\mathbf{R}$ & 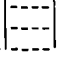 & $\mathrm{c}^{-}$ & $\mathrm{F}$ & & $\left|\begin{array}{l}--- \\
-\cdots-\end{array}\right|$ & $\mathbf{F}$ & $-\cdots$ & 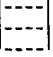 & $\begin{array}{c}-\mathbf{C}^{-} \\
\mathrm{R}\end{array}$ & $\mathrm{R}$ & $\mathrm{F}$ & F & $\begin{array}{l}\mathrm{F} \\
\mathrm{R}\end{array}$ & $\mathrm{C}^{-}$ & $\mathrm{F}$ & C & ; & $\mathrm{C}$ & $\mathrm{C}^{-}$ & $\cdots$ & $\mathbf{R}$ & $\mathbf{R}$ \\
\hline
\end{tabular}


TABLE 15.-Microfossils identified in core samples of pre-Selma Upper Cretaceous sediments in western Alabama-Cont.

[Relative abundance in samples indicated by R, rare; F, frequent; C, common; A, abundant; and D, dominant]

\begin{tabular}{|c|c|c|c|c|c|c|c|c|c|c|c|c|c|c|c|c|c|c|c|c|c|c|c|c|c|}
\hline \multirow{4}{*}{ Species identified } & Name of core... & \multicolumn{9}{|c|}{ Webb core } & \multicolumn{9}{|c|}{ Boykin core } & \multicolumn{6}{|c|}{ Crawford core } \\
\hline & USGS paleobotany locality_. & \multicolumn{9}{|c|}{ D1109 } & \multicolumn{8}{|c|}{ D1111 } & D1457 & \multicolumn{3}{|c|}{ D1456 } & \multicolumn{3}{|c|}{ D1110 } \\
\hline & Formation. & \multicolumn{9}{|c|}{ Coker, Eoline member } & \multicolumn{8}{|c|}{ Coker, Eoline member } & Gordo & \multicolumn{3}{|c|}{ MeShan } & \multicolumn{3}{|c|}{ Eutaw } \\
\hline & Sample No & 10 & 9 & 8 & 7 & 6 & 5 & 4 & 3 & 2 & 10 & 9 & 8 & 7 & 6 & 5 & 4 & 3 & 1 & 6 & 5 & 4 & 3 & 2 & 1 \\
\hline $\begin{array}{l}\text { Cingulatisporites dubius Couper } \\
\text { C. problematicus Couper }\end{array}$ & \multicolumn{25}{|c|}{ rae Dispersae-Continued } \\
\hline ef. C. scrabatus Cot & er & --- & 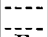 & & & --- & $-\cdots$ & -- & & & & $\mathrm{R}$ & $-\cdots$ & & & &.-- & & $\mathbf{R}$ & & & $\mathbf{R}$ & & & 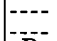 \\
\hline Concavisporites ef. & punctatus Delcourt and & B & $\mathrm{F}^{-}$ & & -- & $-\cdots$ & $\cdots$ & $\mathbf{F}$ & $\mathrm{R}$ & $-\cdots$ & $\bar{F}$ & $\mathrm{C}$ & $\cdots$ & $-\mathbf{F}^{-1}$ & $\mathbf{F}$ & $\mathbf{R}$ & $\mathrm{c}^{-}$ & $\mathrm{C}^{-1}$ & & & $(-\cdots$ & -.. & $\mathrm{R}$ & $\mathbf{F}$ & $\mathbf{R}$ \\
\hline \multirow{2}{*}{\multicolumn{2}{|c|}{$\begin{array}{l}\text { Corrugatsportes arcuatus weyland \& Greiteld } \\
\text { Cyatheacidites annulata Cookson. }\end{array}$}} & $\begin{array}{c}\mathbf{R} \\
-\cdots-\end{array}$ & $-\cdots$ & - & $\mid--1$ & 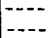 & $\begin{array}{l}--- \\
-\cdots \\
-\cdots\end{array}$ & $\cdots$ & $\mid--s$ & & $\cdots$ & $\cdots$ & $\mid---$ & - & & 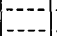 & {$[-\cdots$} & --- & & & - & $R$ & $\mid--$ & $-\cdots$ & -- \\
\hline & & 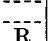 & $\cdots$ & -- & $-\cdots$ & $-\cdots$ & - & . & -- & & - & $\mathrm{B}$ & $-\cdots$ & - & $\mathbf{R}$ & $\cdots$ & $\cdots$ & - & & $\cdots$ & & & -0 & 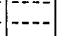 & $\cdots$ \\
\hline \multirow{2}{*}{\multicolumn{2}{|c|}{$\begin{array}{l}\text { Cyathidites mesozoicus (Thiergart) R. Potonié } \\
\text { Deltoidospora hallii Miner- }\end{array}$}} & $\begin{array}{l}\mathbf{R} \\
\mathbf{R}\end{array}$ & $\mid---$ & 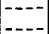 & -- & 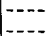 & $-\cdots$ & $-\cdots$ & 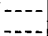 & $\mathrm{C}$ & $\mathbf{F}$ & $\mathbf{K}$ & & & & $=-$ & $\mid----$ & $\because \mathrm{c}$ & & $\cdots-$ & $\cdots$ & $\mathbf{R}$ & & ---- & $\mathbf{R}$ \\
\hline & & & $-\bar{x}$ &.-- & - & $\cdots$ & -- & $\cdots$ & $\cdots$ & & - & $\mathbf{R}$ & - & $\cdots$ & 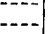 & $-\cdots$ & $\cdots$ & $\ldots$ & $\mathrm{R}$ & 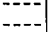 & $\cdots$ & 10 & $\mathbf{R}$ & $-\cdots$ & \\
\hline \multicolumn{2}{|c|}{$\begin{array}{l}\text { Densoisportes perinatus Couper } \\
\text { Gleichenia circinidites Cookson.-... } \\
\text { Gleicheniidites senonicus Ross }\end{array}$} & $\mathrm{R}$ & $-\cdots$ & $-\cdots$ & $-\cdots$ & $-\cdots$ & $-\cdots$ & - & $-\cdots$ & & 等 & & $-\cdots$ & - & , & $-\cdots$ & $-\cdots$ & - & & & - & 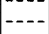 & $\ldots$ & $-\cdots$ & - \\
\hline \multicolumn{2}{|c|}{$\begin{array}{l}\text { Gleicheniidites senonicus Ross- } \\
\text { Hymenozonotriletes reticulatus Bolkhovitina. }\end{array}$} & $-\cdots$ & $-\ldots$ & -2 & & --- & $--\cdot$ & $-\cdots$ & $-\ldots$ & $\mathbf{R}$ & $\mathrm{F}$ & $\mathbf{R}$ & 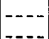 & $-\cdots$ & $-\ldots-$ & --- & $-\cdots$ & & & -- & & $\mathrm{R}$ & --- & --- & -- \\
\hline \multirow{2}{*}{\multicolumn{2}{|c|}{$\begin{array}{l}\text { Leiotriletes cf. L. subtilis Bolkhovitina } \\
\text { Lycopodium cerniidites Ross. }\end{array}$}} & $\begin{array}{l}-\cdots \\
\cdots-1\end{array}$ & $\mathbf{R}$ & ... & $\cdots$ & --- & $\begin{array}{ll}-\cdots \\
\cdots-1\end{array}$ & $\overline{\mathbf{R}}$ & 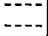 & $\ldots$ & 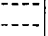 & -..- & {$\left[\begin{array}{c}-\cdots \\
-\cdots-1\end{array}\right.$} & $\cdots$ & - & 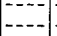 & $\begin{array}{ll}-1 \\
\cdots-1\end{array}$ & $\mathrm{R}$ & & -1 & 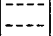 & 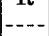 & (n- & $-\infty$ & - \\
\hline & & $\mathbf{F}$ & $\mathrm{R}$ & & $\mathrm{C}^{-}$ & $\mathrm{C}^{-}$ & & $\mathrm{C}$ & $\mathbf{F}$ & $\mathbf{F}$ & $\mathrm{C}$ & $\mathrm{F}$ & $\mathrm{F}$ & & $\mathrm{F}$ & & $\mathbf{F}$ & $\mathrm{C}$ & & $\ldots$ & $\mathrm{C}^{-1}$ & $\mathrm{R}$ & $\mathrm{C}$ & $\mathrm{R}$ & $\mathbf{A}^{-}$ \\
\hline \multicolumn{2}{|c|}{$\begin{array}{l}\text { Monolites major Cookson } \\
\text { Osmundacidites wellmanii Couper }\end{array}$} & & & & & & & & & & & & & & & & & & & & $\mathbf{R}$ & & & & \\
\hline \multirow{2}{*}{\multicolumn{2}{|c|}{$\begin{array}{l}\text { Plicatella trichacantha Malawkina } \\
\text { Polypodiaceaesporites haardti (R. Potoniê and Venitz) }\end{array}$}} & $\mathrm{R}$ & $\mathrm{R}$ & -.- & $\mathbf{R}$ & --- & $\ldots$ & -..- & -.. & 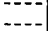 & $\mathrm{R}$ & $\mathbf{R}$ & $-\cdots$ & - n & 烈. & {$[--$} & $-\cdots$ & - n & $\mathrm{R}$ & & $\ldots$ & $\mathbf{R}$ & -..- & 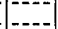 & -. \\
\hline & & $\mathbf{R}$ & R & & $\mathbf{R}$ & & & & & F & & $\mathbf{R}$ & & & & & & & & & $\mathrm{R}$ & & $\mathrm{R}$ & & R \\
\hline \multicolumn{2}{|c|}{$\begin{array}{l}\text { Thomson \& Pflug } \\
\text { Poroplanites porosinuosus Pflug }\end{array}$} & & & $\cdots$ & & & & & & $\mathbf{F}$ & $\cdots$ & $\mathrm{F}$ & & & & $\ldots$ & & $\ldots$ & & & $\mathbf{K}$ & $-\cdots$ & $\mathbf{K}$ & - & K \\
\hline \multirow{2}{*}{\multicolumn{2}{|c|}{$\begin{array}{l}\text { Rugulatisporites quintus Thomson and Pflug } \\
\text { Schizaeoisportites eocaenicus (Selling) R. Potoniế- }\end{array}$}} & $-\cdots$ &.- & $\mathrm{R}$ & $\mathrm{C}^{-1}$ & -..- &.- & -.-- & & & -..- & & --- & & -... & $-\ldots$ & - n- & & & $\ldots$ & $\ldots$ & --- & . & ... & \\
\hline & & -3 & (t) & $\cdots$ & & $\cdots$ & - & $\cdots$ & & $\cdots$ & $\mathbf{R}$ & -- & --- & $\cdots$ & $\mathbf{R}$ & $-\ldots$ & --- & & & & ( &.-- & $\cdots$ & 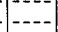 & $\mathbf{R}$ \\
\hline Schizoplanites redu & us Pflug & & $-\cdots$ & --- & --- & $-\cdots$ & $-\cdots$ & $\cdots$ & $\mathbf{R}$ & --- & $-\cdots$ & --- & --- & $-\cdots$ & $\cdots$ & --- & -..- & $-\cdots$ & & $\cdots$ & $-\cdots$ & $-\cdots$ & & $\mathrm{R}$ & \\
\hline Sporite & $\begin{array}{l}\text { art } \\
\text { cus (Bolkhovitina) Stove }\end{array}$ & $\mathbf{R}$ & $-\cdots$ & - & $\cdots$ & --- & $-\cdots$ & $\cdots$ & - & 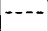 & $\cdots-$ & $\cdots$ & $-\cdots$ & $\cdots$ & $\cdots$ & $-\cdots$ & $-\cdots$ & & & . & $\cdots$ & & $\cdots-$ & $\mathbf{R}$ & \\
\hline $\begin{array}{l}\text { Taurocusporites red } \\
\text { Torisporis intrastru }\end{array}$ & ius (Bolkhovitina) Stover - & & & & & & & & & & & & & & & & & & & & $\cdots--1$ & $\cdots$ & & --- & \\
\hline Trilites verrucatus & per & $\mathbf{R}$ & & $\cdots$ & & $\cdots$ & & & & & & & & & & & & & & & & & & --.- & $\mathbf{R}$ \\
\hline $\begin{array}{l}\text { Trilites undeter } \\
\text { Triplanosporites }\end{array}$ & & R & $\mathbf{F}$ & $\cdots$ & $\begin{array}{l}\mathrm{F} \\
\mathrm{R}\end{array}$ & $\mathbf{F}$ & $\mathbf{R}$ & $\bar{R}$ & F & - & $\cdots$ & $\underset{\mathbf{F}}{\mathbf{F}}$ & - & --- & $-\cdots$ & $\begin{array}{l}\mathrm{R} \\
\mathrm{C}\end{array}$ & $\underset{F}{F}$ & & & $\mathbf{F}$ & $\mathbf{F}$ & F & $\mathrm{C}$ & 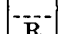 & $\mathbf{R}$ \\
\hline Verrucatosporites a & $a_{s}(\mathrm{I}$ & & & & & & & & & & & & & & & $\mathbf{R}$ & & & & & & & & & \\
\hline
\end{tabular}


Gymnospermae

Abietineaepollenites microreticulatus Groot \& Penny Araucariacites australis Cookson

Caytonipollenites pallidus (Reissinger) Couper

Classopollis classoides Pflug

Cycadopites cf. C. follicularis Wilson and Webster

Dacrycarpites australiensis Cookson \& Pike

"Dacrydiumites florinii" Cookson \& Pike

Ephedra Tournefort ex L

Eucommiidites troedssonii Erdtman -....-.

Gynkaletes $\mathrm{cf}$. G. retroflexus (Luber) Luber
Inaperturopollenites dubius (K. Yotonié \& Venitz) Thom-

Inaperturopolle
son \& Pflug.

son \& Pflug.
Labiisporites granulatus Leschik

Labiis porites granulatus Leschik --..--

Laricoidites magnus (Potonié) R. Potonié \& Venitz....

Monosulcites minimus Cookson

Perinopollenites of $P$ elatoides Couper

Pinuspollenites labdacus (R. Potonié) Raatz.............

Pityosporites microalatus R. Potoniế-

cf. $P$. biformis Rouse

cf. Podocarpus (L'Heritier) Persoon.-.

Sequoiapollenites polyf

Taxodiaepolleniles hialus (R. Potonie) Thiergart.........

Tougapollenites mesozoicus Couper.

Liliacidites intermedius Couper.

Liliacidites intermedius Couper-....

Dicotyledonae:

Triporate pollen:

$B$. orthobasalis (Pflug) Pflug.

Complexipollis praetumescens Krutzsch

Conclaripollis anulopyramis Pflug
Extratriporopollenites audax Pflug-

Latipollis normis Krutzsch

L. subtilis Krutzsch

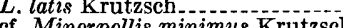

Monstruosipollis monstruosis Krutz...

Nudopollis ornatus (Pflug) Pflug

cf. Oculopollis Pflug -...-...-...

Sporopollis laqueaeformis Weyland \& Greifeld

S. pseudosporites Pflug

Triatriopollenites arboratus Pflug

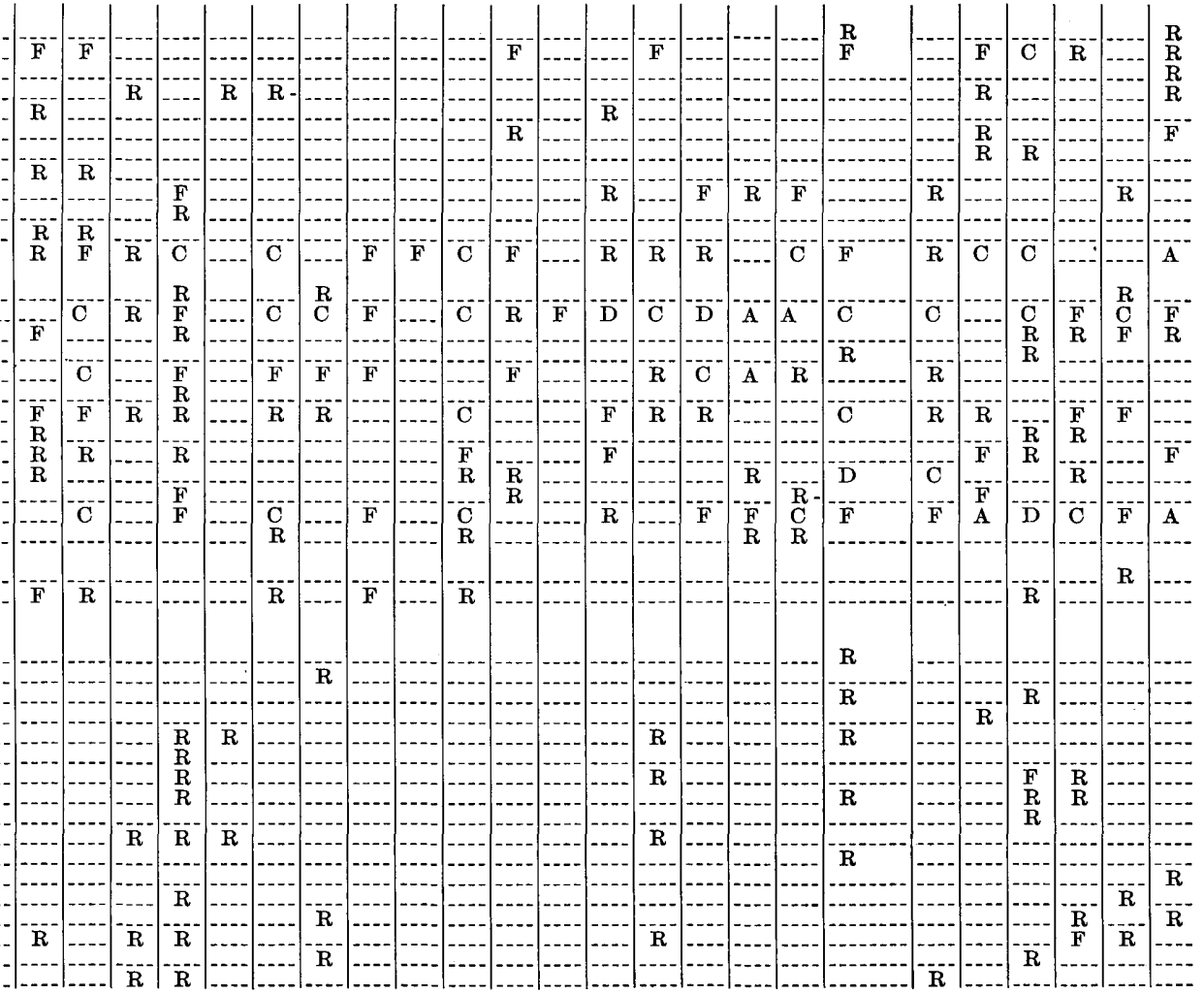


TABLE 15.-Microfossils identified in core samples of pre-Selma Upper Cretaceous sediments in western Alabama-Con.

[Relative abundance in samples indicated by R, rare; F, frequent; C, common; A, abundant; and D, dominant]

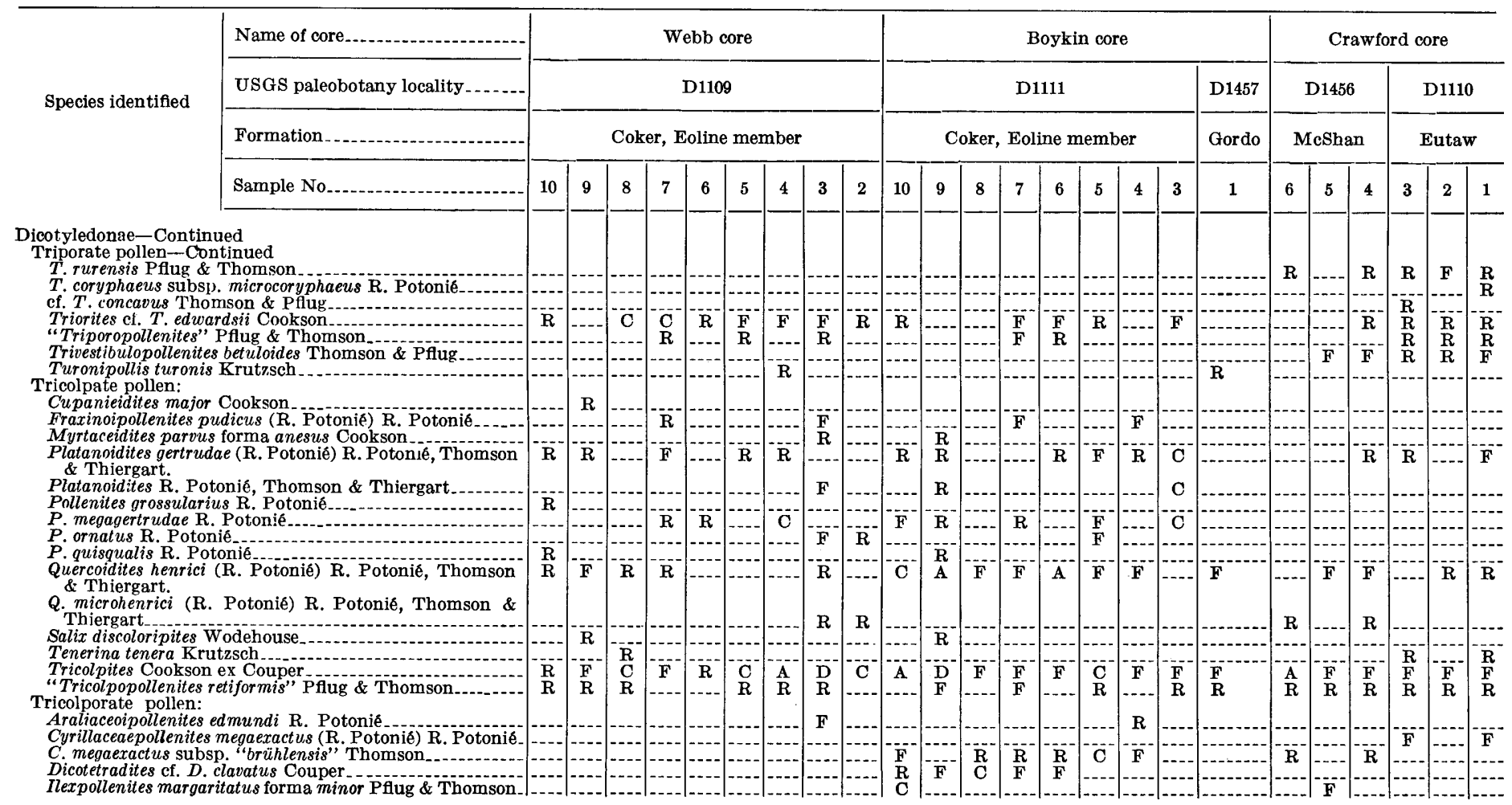


P. genuinus R. Potonié

. kruschi subsp. analepticus R. Potoniê.

Pruschi "asp. pseudolaesus" (R. Potoniê) Thomson \&

Porocolpopollenites Thomson \& Pflug
$P$. orbiformis Thomson \& Pfug
"Tricolporopollenites microreticulatus" Pflug \& Thomson

"T. distinctus" Groot \& Penny

Symplocoipollenites vestibulum (R. Potoniê) R. Potoniế

Tricolporate pollen, undetermined

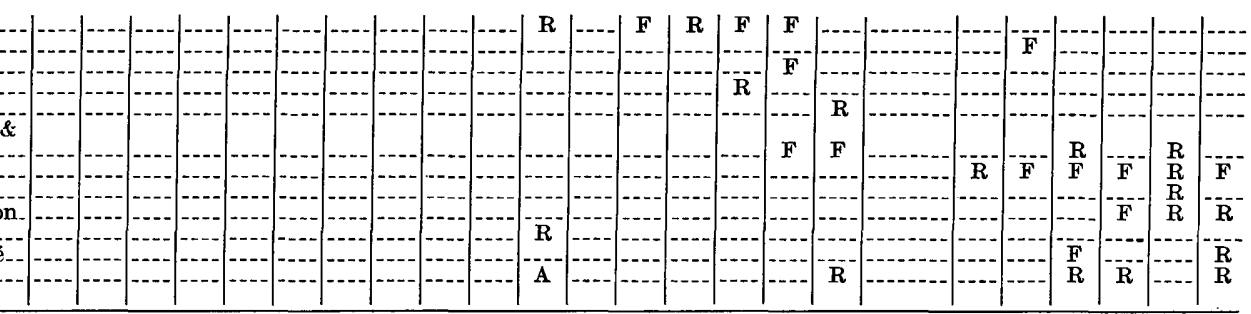


identified here are known to be wide ranging in the Mesozoic and Paleozoic of Europe.

\section{CLASS DINOFLAGELLATA}

Two algal forms in the Eutaw formation are clearly members of the planktonic group Dinoflagellata: Gonyaulax Diesing is a living genus which is entirely an open water plankter, and most of its presently known living species have marine habitats. Paleohystrichosphora infusorioides Deflandre (pl. 9, fig. 14) is a form species typical of marine Upper Cretaceous sediments of Europe. Species of Deflandrea Eisenack similar to the present material (pl. 9, figs. 15, 16) are known from marine Upper Cretaceous through Eocene sediments in Australia.

\section{ORDER CHROOCOCCALES}

A colonial alga composed of 15 cells embedded in a filmy, if not gelatinous, envelope, and having smooth ovoid cells 7 by 4 microns in size, appears to be a member of the Chroococcales. The form resembles the modern genus Aphanocapsa.

\section{ORDER I YCOPODIACEAE}

A member of the Lycopodiaceae, Lycopodium cerniidites Ross resembling the modern subtropical species Lycopodium cernuum L. occurs in the Coker and McShan formations. Leaves and strobili of Lycopodium and leaves of Lycopodites were found in the Tuscaloosa flora by Berry (1919), who stated elsewhere (Berry, 1910) that Lycopodium megafossils are rare in the American Cretaceous.

\section{CLASS FILICINEAE}

Of the 30 species of pteridophyte spores identified from the preSelma samples, only 7 can be assigned to modern families with certainty, and only 1 represents a living genus.

The terrestrial fern family Schizaeaceae, which has four living component genera, is well represented in the Tuscaloosa group (pl. 3, figs. 1-13; pl. 6, figs. 1-5). The organ genus Plicatella Malawkina has affinities with a part of the modern genus Anemia Swartz, especially with the living species $A$. adiantifolia (L.) Swartz. Cicatricosisporites R. Potonié and Gelletich has affinities both with Anemia and Mohria Swartz, and Schizaeoisporites Potonié closely resembles its living counterpart Schizaea Smith, especially S. digitata (L.) Swartz. All living species of Schizaeaceae are restricted to subtropical and tropical regions, except two species of Schizaea which have boreal distributions. Fossil spores are the only evidence of this family in these pre-Selma strata. 
Spores assignable to the modern austral and tropical fern genus Gleichenia Smith are present in the Eoline member of the Coker formation. Our specimens are of the G. circinata type and compare in all respects with Cookson's late Mesozoic species $G$. circinidites Cookson. Spores of probable affinities with the Gleicheniaceae are represented by the species Gleicheniidites senonicus Ross. Megafossils of Gleichenia were found by Berry (1919) within the Tuscaloosa group at Shirleys Mill, Ala. That leaf locality is considered by Monroe (written communication, 1960) to be part of the Coker formation.

\section{CLASS GYMNOSPERMAE}

Of 22 genera of gymnosperm pollen, 18 of which are identified on the species level, 1 is a living genus, and about half of the species can be assigned to modern families. By far the most interesting aspect of the gymnospermous forms reported here are those which assuredly represent the now exotic family Podocarpaceae. Except for a single report of Podocarpus (L'Heritier) Persoon in northeastern Mexico (Sharp, 1949), evidence indicates that living members of this family are restricted to the Southern Hemisphere. The fossil forms are as follows:

Fossil form

Dacrycarpites australiensis Cookson \& Pike (pl. 7, figs. 1-2)

"Dacrydiumites (Phyllocladites) florinii" Cookson \& Pike

Parvisaccites radiatus Couper (pl. 7, fig. 3)

cf. Podocarpus (an unnamed pollen genus) (pl. 7, fig. 7)

Podocarpidites cf. P. biformis Rouse (pl. 7, figs. 12-13)

Podocarpidites cf. P. major Couper (pl.4, figs. 11-13 and, pl. 7, figs. 4-6).
Affinity

Podocarpus (L'Heritier) Persoon, section Dacrycarpus

Dacrydium Soland (group b of Cookson, 1953)

Dacrydium cupressinum Soland ex Forster f.

Podocarpus and Phyllocladus Rich

Podocarpus

Podocarpus

Reports of fossil remains of undoubted Podocarpaceae in the United States are rare in the paleobotanical literature. A podocarpaceous plant from the Tuscaloosa group, known to have been widespread in Cretaceous vegetation of west-central and eastern United States (Dakota, Magothy, and Raritan formations), is Protophyllocladus subintegrifolius (Lesquereaux) Berry, but its actual relation to the modern genus Phyllocladus is still in doubt, according to Berry (1919, p. 58). Two species of American Eocene woods, Podocarpoxylon washingtonense Torrey and $P$. texense Torrey, may be assigned to the Podocarpaceae according to an evaluation by Kräusel (1948). A study of Lower Cretaceous or Upper Jurassic pollen from British 
Columbia by Rouse (1959) provided the first published evidence that pollen assignable to the Podocarpaceae is represented in North American Mesozoic strata.

Pollen of the Podocarpidites biformis type is, according to our observations, common in Lower Cretaceous sediments of Wyoming and very rare in younger strata of that area.

Another interesting pollen is Caytonipollenites pallidus (Reissinger) Couper in the Eutaw formation (pl. 6, figs. 33 and 34), a species which Couper (1958) has shown represents pteridosperm pollen and assigned provisionally to the family Caytoniaceae. Pollen forms of this sort are known in Triassic and Jurassic rocks of Utah (R. A. Scott, oral communication, 1960), and are common in Upper Jurassic and less common in Lower Cretaceous sediments (Lower Greensand or Aptian) of England (Couper, 1958). Megafossil remains of the pteridosperms, or seed ferns, are known to range from Mississippian through Jurassic (Arnold, 1947); published records of the unique order Caytoniales demonstrate only Jurassic and Lower Cretaceous occurrences. As far as we know, the Caytonipollenites in the Eutaw formation represents the first Upper Cretaceous record of Pteridospermae.

The broad-leaved conifer family Araucariaceae, now distributed mainly in temperate climates and now limited to the southern hemisphere, is represented by pollen in all four formations of this study by the pollen genus Araucariacites Cookson (pl. 6, fig. 29), which closely resembles modern pollen of Araucaria Jussieu and Agathis Salisbury species. The family is represented in the Eutaw and McShan floras by leaves assigned to the species Araucaria bladensis Berry and $A$. jeffreyi Berry (Berry, 1919).

Couper (1958, p. 130) has suggested that the pollen genus Classopollis (Pflug) Couper, of which two species were found in the preSelma sediments, might have its affinities with the family Araucariaceae on the basis of the similarity of the genus to the pollen of Pagiophyllum Heer, a provisional fossil member of the family. Pollen of $C$. classoides Pflug is figured on plate 6 (figs. 30-32).

Classopollis and Araucariacites are common in our Upper Cretaceous collections from Colorado and Wyoming and occur occasionally in lower Paleocene sediments of Wyoming.

Three species of the pollen assemblage as identified here are clearly members of the Taxodiaceae, resembling pollen of Taxodium Rich and Sequoia Endlicher; these are Taxodiaepollenites hiatus (Potonié) Thiergart, Inaperturopollenites dubius (Potonié \& Venitz) Thomson \& Pflug (pl. 6, figs. 25-28), and Sequoiapollenites polyformosus Thiergart (pl. 4, fig. 1). Individual pollen grains of Taxodiaceae are rarely sufficient to identify even genera in modern material; but tallies of 100 grains from acetolysed pollen taken from male cones of all living genera of 
Taxodiaceae indicate that Taxodium pollen differs from that of the other members of the family in at least two features. Taxodium pollen is characterized by a relatively thin cell wall which contributes to characteristically high frequency (20 to 75 percent) of split pollen, while among pollen of other Taxodiaceae, splitting is generally less than 5 percent. Taxodium pollen is also characterized by the small number (less than 15 percent) of grains bearing papillae; but at least among the nearest relatives of Taxodium, papillae occur on from 66 to 99 percent of the pollen grains. (Lacking papillae, Cunninghamia R. Brown and Athrotaxis D. Don pollen differ from that of Taxodium by having especially thick walls; Cupressaceae pollen are not considered here because they differ from the fossils in question in having larger gemmae scattered on the exteriors of the pollen walls.)

In the present material, we have discovered that the split pollen grains of the Taxodium type, assigned to Taxodiaepollenites hiatus (pl. 6, figs. 27 and 28), are somewhat more numerous in each sample than unbroken spherical pollen of the same type, assigned to Inaperturopollenites dubius (pl. 6, figs. 25 and 26). As can be seen in table 15, T. hiatus and I. dubius occur together in almost every sediment sample examined, and are especially abundant in sediments of the Coker formation.

Though leaves and twigs from the Tuscaloosa group have been assigned to three species of the genus Sequoia Endlicher by Berry (1919), papillate pollen that might represent Sequoia (pl. 4, fig. 1) were found to be exceedingly rare in the present material.

Pollen representing two forms of the modern genus Ephedra Tournefort ex L. are the only fossils of the Gnetaceae yet uncovered in the Tuscaloosa group, but the genus is known to range from Triassic to Recent (Scott, 1960). One form that is like the pollen of the living species $E$. torreyana is figured on plate 6 (figs. 23 and 24).

Pollen assigned to the species Pityosporites microalatus R. Potonié and Pinuspollenites labdacus (R. Potonié) Raatz represent Pinaceae cf. Pinus (Tournefort) L. (pl. 4, figs. 4-10). Megafossil remains of Pinus have been described from middle and lower beds of the Tuscaloosa group and are known from other Upper Cretaceous deposits in the United States. Tsugaepollenites mesozoicus Couper may be considered a member of the pine family, having affinities with Tsuga Carrière.

The members of the gymnosperm list in table 15 not mentioned in this discussion are gymnospermous pollen of uncertain position.

\section{CLASS ANGIOSPERMAE}

The angiosperm flora as represented by pollen, like the megafossil forms of the pre-Selma strata, is primarily dicotyledonous. Only two pollen types, Sabalpollenites areolatus (R. Potonié) R. Potonié 
and Liliacidites intermedius Couper (pl. 7, figs. 16-18) can be considered monocots, but these are not assignable to living families because their morphology is suggestive of several: Palmae, Bromeliaceae, Calycanthaceae, or Liliaceae.

The Dicotyledonae of the flora represented by pollen include 55 forms or 40 identified species, a relatively unimpressive number when compared with 123 dicot species that have been described from leaves from the Tuscaloosa group (Berry, 1919). But where pollen can be assigned to still existing dicot families, an interesting corroboration of taxa exists between pollen and megafossil evidence. Pollen species assigned to dicotyledonous families are listed below in table 3 along with their distribution in the pre-Selma Cretaceous formations:

TABLE 16.-Dicotyledonous families represented by pollen in pre-Selma strata

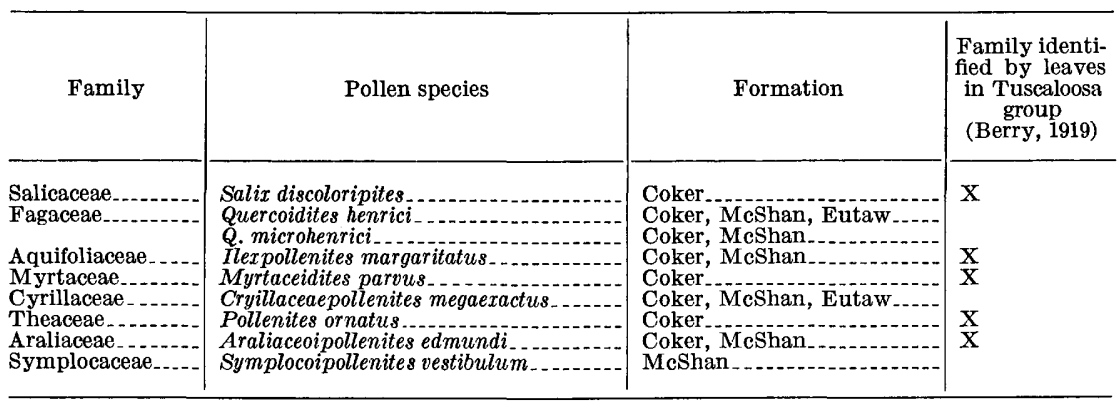

The family Salicaceae is represented in the flora by leaves assigned to Salix (Tournefort) L. and Populus L. by Berry (1919), and by Salix pollen as listed above in table 16. The few specimens we have assigned to Salix are entirely like modern Salix pollen of the S. discolor Muhl. type.

Some of the specimens referred to Quercoidites henrici (R. Potonié) R. Potonié, Thomson \& Thiergart (pl. 5, figs. 10-11) seem to be quite like the pollen of modern Quercus (Tournefort) L. but the others seem tricolporoid, perhaps like Fagus (Tournefort) L. We consider these tricoplate forms, which occur in three pre-Selma formations, sufficiently diagnostic to assign them to the family Fagaceae. No members of the family were found in the Tuscaloosa group by Berry (1919).

Large and small pollen of the family Aquifoliaceae, common in the Coker formation, are assigned to forms of the organ species Ilexpollenites margaritus (R. Potonié) Thiergart. As in certain European Tertiary material of this species, our specimens resemble the pollen of the genus Ilex (Tournefort) L. and Nemopanthus Raf., but the size of the clavae and, for the most part, the size of the pollen cell are much smaller than in pollen of living Ilex or Nemopanthus species. The pollen morphology of the family is so unique among living dicots 
that there can be little mistake about the affinity cited. Hollylike leaves assigned to Ilex, which are similar to leaves of modern Ilex species in margins and veination, are mentioned by Berry (1919) as being frequent in sediments of the Tuscaloosa group.

The dicotyledonous pollen listed in table 15 as Platanoidites sp. is a unique form resembling pollen of the plane tree, Plantanus occidentalis, in having a pronounced membrane across the colpae, and very obvious gemmae of uniform size on the colpae membranes: these unusual features are known to us in the pollen of the Platanaceae and Hammamelidaceae. Though several species of leaves from the Tuscaloosa were assigned to the Platanaceae (Berry, 1919), their morphology was more conclusive than that of the pollen we have identified as Platanoidites (pl. 5, figs. 14-15).

Pollen of the Cyrillaceae is represented in the flora of the Gordo and McShan formations by the species Cyrillaceaepollenites megaexactus (R. Potonié) R. Potonié. Though Potonié (1960, p. 102) has synonymized the C. megaexactus forma "brühlensis" Thomson with the species $C$. megaexactus we refer to the form here because its type provides more convincing evidence for assignment in this family than the type for C. megaexactus. As in the Rheinish lignite specimens on which this species was founded (Potonié, 1931), the range in morphology within $C$. megaexactus includes the pollen characters of both Cliftonia Banks et Gaertner and Cyrilla Gardner. Also the fossil material exhibits a somewhat greater range of variation in wall structure or texture than modern reference material of the family we have seen. Remains of Cyrillaceae are reported in the Brandon lignite (Oligocene) of Vermont (Traverse, 1955), but we know of no other fossils of the group yet recorded in the American literature. European fossils of the family are main!y of middle and late Tertiary age.

Pollenites ornatus R. Potonié, found in the Coker formation, was first described from Eocene lignites of Germany by Potonié (1934), who suggested that the species is similar to pollen of Jasaminum (Tourefort) $\mathrm{L}$. of the Oleaceae. Specimens assignable to $P$. ornatus from the Tuscaloosa group, and some specimens in U.S. Geological Survey collections from the Laramie formation of Late Cretaceous age in Colorado, are closely similar to the pollen morphology of Gordonia Ellis or Schima Reinwardt ex Blume of the Theaceae; in our material this similarity suggests an affinity with that family. No megafossil remains from the Tuscaloosa group have thus far been assigned to the Theaceae.

Two species sporadically distributed in the Coker and Gordo formations are Myrtaceidites parvus forma anesus Cookson of the Myrtaceae, and Cupanieidites major Cookson of affinities with either Myrtaceae or Sapindaceae. These forms occur in Upper Cretaceous 
and lower Paleocene strata in Colorado and Wyoming. Megafossil forms having affinities with Eucalyptus L'Heritier and Eugenia Michaux ex L. of the Myrtaceae are cited by Berry (1919) in the Tuscaloosa flora, but he recorded no sapindaceous megafossils.

\section{PALYNOMORPH ZONES OF THE PRE-SELMA STRATA}

Although many components of the pre-Selma pollen and spore flora have a somewhat random distribution within the four formations, a number of species seem to be restricted to certain parts of this section, or show definite changes in abundance within the section. Rather clear differences also exist between the laterally equivalent parts of the Eoline member of the Coker formation in the Boykin and Webb cores. These differences, which apparently represent facies changes, suggest that definition of pollen zones here should be undertaken with some caution. Berry (1919), in his study of the plant remains, noted only minor differences between the flora of the Tuscaloosa group and that of the McShan and Eutaw formations, and comparatively small floristic changes from bottom to top within the Tuscaloosa group (Berry, 1919, p. 22).

With respect to the palynomorphs identified here, including the algae and hystrichomorphs, significant changes exist at only one level within the pre-Selma section, and these occur at or near the top of the Tuscaloosa group. These changes involve a partial replacement of land plants by aquatic forms as well as a significant change in species of land plants.

\section{FACIES CHANGES}

The replacement of land plants by aquatic forms appears rather abruptly near the base of the McShan formation. Clay above the basal sandy gravel of the McShan formation in the Crawford core contains a mixed gymnospermous and dicotyledonous land plant assemblage and very occasional hystrichomorphs (algae?), but the clay only 12 feet higher in the core contains predominantly microforaminifer remains; hystrix forms are both varied and more abundant, and land plant forms are numerically unimportant. Near the top of the McShan formation and in the middle part of the Eutaw formation, remains of microforaminifers are frequent to dominant-hystrix and dinoflagellate algae occurring regularly. That this change is related to increased depth of water is suggested by the overall lithologic evidence and by modern environments in which microforaminifers accumulate.

A study of the sedimentary environment of some marine microorganism remains within Kapingamarangi lagoon by McKee, Chronic, and Leopold (1959) indicates that microforaminifers occur in small numbers in several sediment types on the lagoon floor, but their numbers per gram of bottom sediment are especially great in the environ- 
ment where clay-sized particles are the chief constituent of the sediment. At Kapingamarangi, this environment is where water depths are from 225 to 240 feet, the deepest and quietest part of the lagoon floor. Though little is yet known about their taxonomy, these microforaminifera ( $<150$ microns) from Kapingamarangi are taxonomically distinct from both the "larger" $(>1 \mathrm{~mm})$ and "smaller" (150 microns to $1 \mathrm{~mm}$ ) Foraminifera (in the usage of Wilson and Hoffmeister, 1952, p. 26).

The Kapingamarangi study (McKee, Chronic, and Leopold, 1959) also demonstrated that planktonic dinoflagellate algae and their hystrixlike resting cysts accumulate primarily in the deeper parts of the lagoon along with the clay-sized sediments; that these microorganisms are deposited allochthonously in water below wave base at Kapingamarangi lagoon is of interest here.

The apparent absence of microforaminifers and scarcity of dinoflagellate algae in the Tuscaloosa group and their presence in large numbers in the McShan and Eutaw formations may be attributed to environmental factors. Several lines of evidence suggest that sediments of the Tuscaloosa group were deposited in shallow water and were oxidized intermittently during deposition. The presence in the Eoline member of the Coker formation of lignite beds and crossbedded glauconitic sands with oysters and brackish-water larger Foraminifera (Applin, chap. D of this bulletin) point to a shallow water lagoonal or shoreline environment of deposition for that member. The variegated color and the general absence of glauconite in sediments of the upper member of the Coker formation suggest a very shallow water environment in which possibly the sediments were intermittently exposed to the air during deposition, as perhaps in a tidal flat environment.

In contrast, the comparatively great amounts of glauconitic sand and absence of lignite beds or oxidized zones in the McShan and Eutaw formations suggest a depositional environment of somewhat deeper water than that of the Tuscaloosa group. The great numbers of microforaminifers, along with the other remains of marine life such as sharks' teeth (Monroe, 1955) and oysters and other mollusks (Sohl, chap. C of this bulletin) in the McShan and Eutaw formations, strongly support this interpretation.

\section{FLORISTIC ZONES}

Of the 105 species in the total palynomorph flora, 34 are in the Tuscaloosa group, but not in the McShan and Eutaw formations. Conversely, 22 species in the McShan and Eutaw formations seem to be lacking in the Tuscaloosa flora (table 17). Disregarding the assortment of algae and microforaminifer remains, 13 species of the

679-264 $0-64-8$ 
TABLE 17.-List of palynormorphs of restricted distribution within the pre-Selma section

Forms in Tuscaloosa group, not found in McShan and Eutaw formations

Hystrichosphaerideae:

Micrhystridium inconspicuum

Sporae Dispersae:

Taurocusporites reduncus

Cicatricosisporites brevilaesuratus

C. dunrobensis

Cingulatisporites problematicus

Concavisporites rugulatus

Cyatheacidites annulata

Cyathidites mesozoicus

Gleichenia circinidites

Gleicheniidites senonicus

Leiotriletes cf. L. subtilis

Lycopodium cerniidites

Poroplanites porosinuosus

Rugulatisporites quintus

Schizoplanites reductus

Torisporis intrastructurius

Gymnospermae:

Classopollis torosus

"Dacrydiumites florinii"

Eucommiidites troedsonii

Pinuspollenites labdacus

Tsugaepollenites mesozoicus

Monocotyledonae:

None

Dicotyledonae:

Triporate pollen:

Basopollis atumescens

$B$. orthobasalis

Extratriporopollenites audax

Latipollis normis

Monstruosipollis monstruosis

Turonipollis turonis

Tricolpate pollen:

Cupanieidites major

Fraxinoipollenites pudicus

Myrtaceidites parvus

Pollenites megagertrudae

$P$. ornatus

Salix discoloripites

Tricolporate pollen:

Araliaceoipollenites edmundi

Pollenites genuinus
Forms in MeShan and Eutaw formations, not found in Tuscaloosa group

Hystrichosphaerideae, microforaminifers, and dinoflagellate algae: Hystrichosphaera cornigera Membranilaranx pterospermoides Schizosporis reticulatus

Pterospermopsis ginginensis

Micrhystridium bacilliferum

$M$. parvispinum

$M$. pavimentum

Microforaminifers

Paleohystrichosphora infusorioides

Sporae Dispersae:

Baculatisporites primarius

Corrugatisporites arcuatus

Hymenozonotriletes reticulatus

Osmundacidites wellmanii

Gymnospermae:

Caytonipollenites pallidus

Dacrycarpites australiensis

Monocotyledonae:

Liliacidites intermedius

Dicotyledonae:

Triporate pollen:

Triatriopollenites rurensis

T. coryphaeus

Trivestibulopollenites betuloides

Tricolpate pollen:

None

Tricolporate pollen:

Pollenites cingulum

Porocolpopollenites

"Tricolporopollenites microreticulatus"

Symplocoipollenites vestibulum 
MeShan-Eutaw flora do not occur in the Tuscaloosa group. Our data indicate that of the 90 nonaquatic species, the combined differences between the floras of the Tuscaloosa group and of the McShan and Eutaw formations amount to about 55 percent of the land-plant flora. Because of the limited scope of the sampling for the present report, we feel that some of the floristic differences now apparent between these two segments of pre-Selma strata may disappear with exhaustive sampling and larger tallies. In part, this might be expected because about two-thirds of the forms in table 17 are known to have a wide distribution within the Cretaceous.

Part of the differences in floras of the Tuscaloosa group and of the McShan and Eutaw formations may be explained by evolutionary changes. The dicotyledonous flora of the Eoline member of the Coker formation contains a group of very distinctive triporate Normapolles Pflug types which are very similar to some of the earliest dicot pollen types from the European Cretaceous section, and these distinctive forms are so different from pollen of modern groups that no affinities with modern families can be cited. These forms include several species that Krutzsch (1959) has described and figured from Turonian sediments of Germany, which are well dated by the presence of Inoceramus labiatus (Schlotheim) and Scaphites geinitzi (d'Orbigny) fossils.

The distinctive Normapolles forms are listed below with their known stratigraphic ranges according to Krutzsch $(1957,1959)$ :

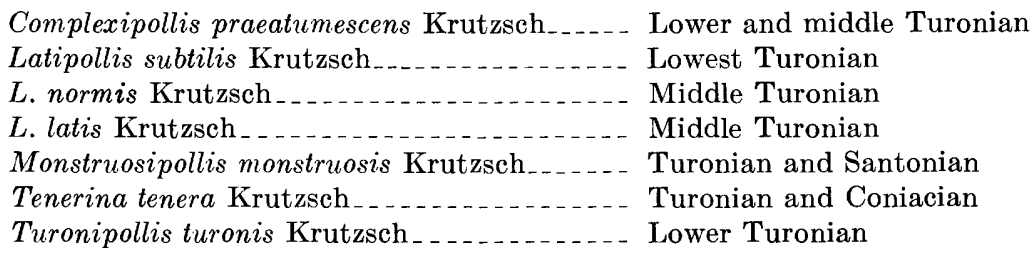

Five of these species seem to be restricted to the Turonian in Germany and the other two range from Turonian through Coniacian and Santonian strata respectively. All these forms are present in the Eoline member of the Coker formation, and half of them also occur in the McShan-Eutaw collections. No other records on these species except those by Krutzsch $(1957,1959)$ are available to us at the time of this writing.

These dicot pollen types are less numerous in the McShan-Eutaw flora, and accompanying them are a group of simple triporates that are not seen in the Tuscaloosa group: Trivestibulopollenites betuloides Thomson and Pflug, Triatriopollenites-coryphaeus (R. Potonié) Thomson and Pflug, T. rurensis Pflug and Thomson, which closely resemble pollen of modern Betulaceae genera, and cf. T. concavus Thomson and Pflug which is similar to some living Myrtaceae forms. 
Appearing in every pollen sample of the McShan-Eutaw strata are many diverse species (mainly unnamed) of the genus Porocolpopollenites Thomson \& Pflug, which are indeed absent in Tuscaloosa group sediments. (According to Potonié (1960), the genus Porocolpopollenites is synonomous with Symplocoipollenites Potonié 1951, but we do not agree. Both are valid genera.)

The Tuscaloosa group also has a very much richer fern flora than the overlying strata and contains several forms not found in the McShan and Eutaw-for example, Leiotriletes, Cingulatisporites, Hymenozonotriletes, and others listed in table 4.

Further zonation of these pre-Selma strata may well be possible by additional sampling and statistical tallies of forms. We expect that in a later report on the flora of these strata we shall be able to present histograms demonstrating more precisely relative abundance of forms.

\section{STRATIGRAPHIC INTERPRETATION AND AGE OF THE FLORAS}

The forms that probably are of greatest use in correlating the flora from the pre-Selma strata with other floras are the dicotyledons. Available records of Cretaceous floras clearly indicate that the percent of dicot forms in the total assemblage, and the stage of evolution these dicots represent, are far more valuable criteria for generalized dating within Cretaceous rocks than the use of individual lower plant forms or groups. With this in mind, a comparison of the dicotyledons of this flora with those of other dated floras from the region is pertinent.

In a recent summary of the pollen floras in the Potomac group of Cretaceous age in the eastern United States, Groot and Penny (1960) stated that dicot pollen represent less than 28 percent of pollen and spore tallies within those strata. In table 18 , the range of percentages for the Raritan formation and older Cretaceous strata are listed, along with a tally from USGS collections from the type section of the Magothy formation; ages of the formations are listed according to Dorf (1952) and the Stephenson committee (Stephenson and others, 1942).

By comparison, the average of 39 and 38 percent of dicots in the Tuscaloosa and McShan-Eutaw floras, respectively, is higher than percent of dicots for the Potomac group as observed by Groot and Penny (1960) and significantly lower than their percentage in the available USGS material from the Magothy formation.

In a recent evaluation of evidence concerning the evolutionary rise of the angiosperms, Scott, Barghoorn, and Leopold (1960) concluded that many of the pre-Cretaceous fossil "angiosperms" are of questionable affinities, that the preponderant clear evidence of early angiosperms indicates that they first appear in the fossil record in 
TABLE 18.-Comparative percentages of dicot pollen and spore tallies of the Potomac group of Maryland and Delaware (Groot and Penny, 1960) and pre-Selma Cretaceous strata of Alabama

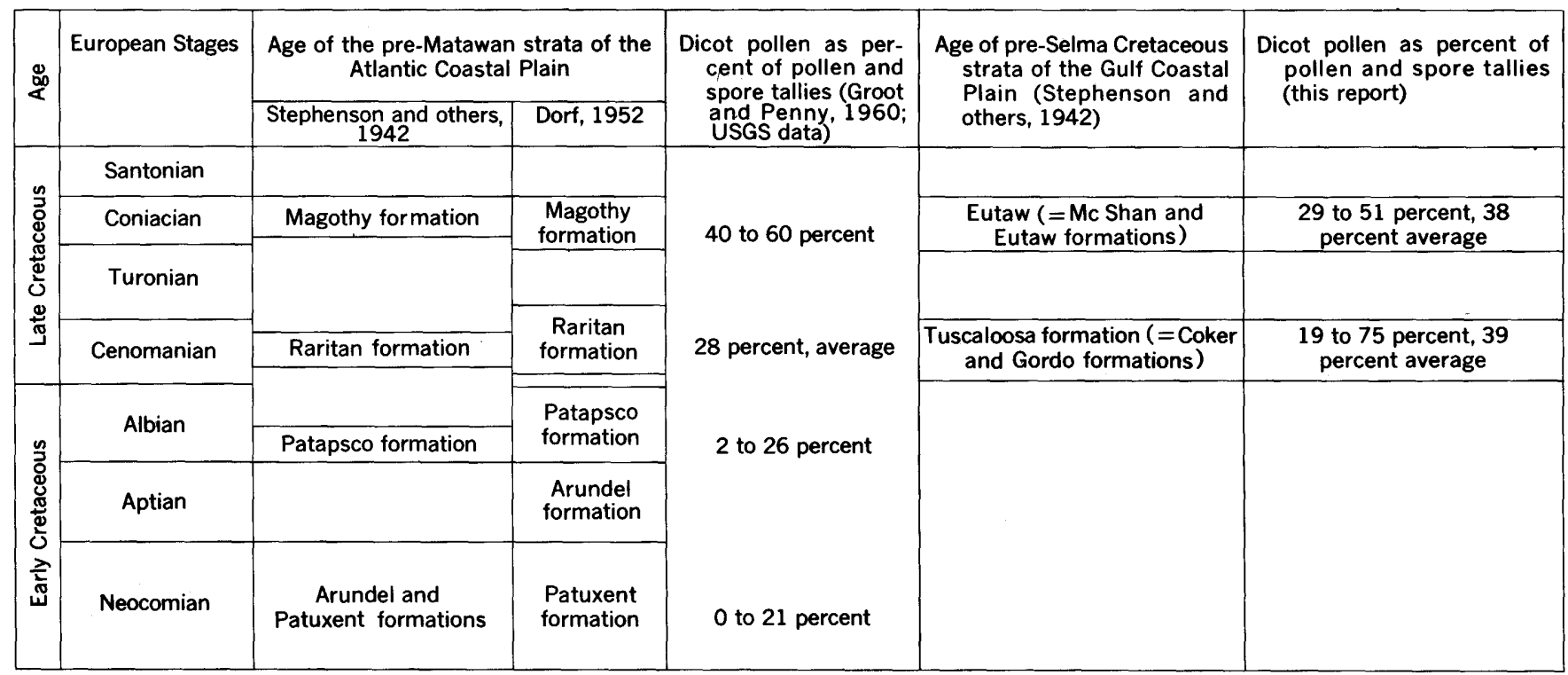


late Early Cretaceous (Albian) time, and that their remains are infrequent until early Late Cretaceous (Cenomanian stage). In a sample of the Patuxent formation (table 18), Groot and Penny (1960) recorded as much as 21 percent angiosperm pollen, but, because they recognized that some of their data were at variance with those from other Neocomian material, they concluded that the angiosperm-rich material very probably is younger than Neocomian (Groot and Penny, 1960, p. 228). Pollen and spore tallies are not available from European Cenomanian through Coniacian and Senonian strata but floral lists indicate that the first striking increase in dicot species occurs in the Turonian (Krutzsch, 1957).

Comparison of the actual species of the Tuscaloosa and EutawMcShan floras with our collections from the Magothy formation (USGS Paleobotany loc. D1322) indicates a marked similarity of the floras; many of the dicot as well as gymnosperm species are in common. In addition, an array of highly distinctive dicot pollen types (for example Oculopollis Pflug, Trudopollis Pflug, and others) that are known from the Senonian of Europe (Weyland and Greifeld, 1953) occur in the Magothy in profusion, but are essentially rare or lacking in the pre-Selma material. (We report one tentatively identified Oculopollis specimen in our youngest sample.)

About half of the 20 forms that Groot and Penny (1960) described from the Potomac group also are represented in the pre-Selma floras. Most of the dicots described by Groot and Penny are of simple, primitive morphology, being mainly of tricolpate and tricolporoid structure.

The most rewarding comparison of the pre-Selma floras is with the material of Krutzsch $(1957,1959)$ from five Turonian localities in Germany. From a third to a fourth of the dicots in the present material, which have not been previously described from American material, occur in Krutzsch's assemblages of Turonian age. These forms are structurally complex, with gross morphology so different from that of known living dicots that their relations to extant plant families are not at all understood. They include the form genera Complexipollis, Latipollis, Turonipollis, Sporopollis, Monstruosipollis, Tenerina, and others.

One dicot species in the flora at hand, cf. Paliurus rhamnoides Bolkhovitina, is named from Cenomanian and Turonian strata of central Russia (Bolkhovitina, 1953). Several fern spores named from Lower Cretaceous strata of Russia (for example, Hymenozonotriletes, Leiotriletes, and "Chomotriletes" (now Taurocusporites) reduncus of Bolkhovitina, 1953) are present also, but these are known to be wide-ranging Cretaceous forms. 
Pollen data from the Raritan and Magothy formations reported by Margaret W. Steeves ${ }^{1}$ indicate that a gradual increase in species and numbers of dicot pollen occurs within the Raritan formation. Because of their unique morphologies, many of these dicot forms cannot be assigned to modern families. We have not compared our material directly with Dr. Steeves' flora, but her observation that the upper parts of the Raritan formation are rich in dicotyledonous forms suggests that a careful comparison of the Raritan flora with the present material might be profitable indeed.

The Tuscaloosa and McShan-Eutaw floras, lacking the structurally advanced forms of Oculopollis and Trudopollis, are pre-Senonian in age, and probably they are older than the Magothy formation in its type area in Maryland. That these floras are younger than the parts of the Potomac group as reported by Groot and Penny (1960) is shown by the relatively higher compositional percentages of dicots, and by the more advanced morphology of the dicot forms represented in the pre-Selma floras. The unpublished data of Steeves concerning the Raritan pollen flora is permissive evidence for the correlation of the upper part of the Raritan formation with the Coker formation, as suggested by Stephenson and others (1942). The similarity of the dicot forms of the pre-Selma Late Cretaceous floras with those of uppermost Cenomanian, Turonian, and Coniacian deposits of Germany (Krutzsch, 1957), supports an early Late Cretaceous age for the floras in the Tuscaloosa group and the McShan and Eutaw formations.

\section{REFERENCES}

Arnold, C. A., 1947, An introduction to paleobotany: New York, McGraw-Hjll Book Co., 433 p.

Braarud, T., 1945, Morphological observations on marine Dinoflagellate cultures: Norske Vidensk. Akad. Avh. I. Mat.-Naturv. Kl., no. 11.

Berry, E. W., 1910, A Cretaceous Lycopodium: Am. Jour. Sei., 4th ser., v. 30, p. $275-276$.

1919, Upper Cretaceous floras of the eastern Gulf region in Tennessee, Mississippi, Alabama, and Georgia: U.S. Geol. Survey Prof. Paper 112, 177 p.

Bolkhovitina, N. A., 1953, Spores and pollen characteristic of Cretaceous deposits of central regions of the U.S.S.R.: U.S.S.R. Acad. Sci., Inst. Geol. Sci. Trans., Rel. 145, Geol. ser. no. 61, 184 p.

Cookson, I. C., 1947, Plant microfossils from the lignites of Kerguelen Archipelago: British, Australian and New Zealand Antarctic Research Expedition 1929-31, Repts. ser. A, v. 2, pt. 8, p. 127-142.

1953, The identification of the sporomorph Phyllocladidites with Dacrydium and its distribution in southern Tertiary deposits: Australian Jour. Botany, v. 1 , no. 1 , p. $64-70$.

- 1953, Difference in microspore composition of some samples from a bore at Comaum, South Australia: Australian Jour. Botany, v. 1, no. 3, p. 462-473.

\footnotetext{
1 Steeves, Margaret W., 1959, The pollen and spores of the Raritan and Magothy formations (Cretaceous) of Long Island: Radcliffe College, Cambridge. Mass., Ph. D. dissertation.
} 
Cookson, I. C. 1956, Additional microplankton from Australian Late Mesozoic and Tertiary sediments: Australian Jour. Marine Freshwater Research, v. 7, no. 1 , p. 183-192.

Cookson, I. C., and Dettman, M. E., 1959, On Schizosporis, a new form genus from Australian Cretaceous deposits: Micropaleontology, v. 5, no. 2, p. 213-216.

Cookson, I. C., and Duigan, S. L., 1951, Tertiary Araucariaceae from Southeastern Australia with notes on living species: Australian Jour. Sci. Research, v. 4, p. 415-449.

Cookson, I. C., and Pike, K. M., 1953, The Tertiary occurrence and distribution of Podocarpus (Section Dacrycarpus) in Australia and Tasmania: Australian Jour. Botany, v. 1, no. 1, p. 71-82.

- 1953, A contribution to the Tertiary occurrence of the genus Dacrydium in the Australian region: Australian Jour. Botany, v. 1, no. 3, p. 474-484.

1954, Some dicotyledonous pollen types from Cainozoic deposits in the Australian region: Australian Jour. Botany, v. 2, no. 2, p. 197-219.

Couper, R. A., 1953, Upper Mesozoic and Cainozoic spores and pollen grains from New Zealand: New Zealand Geol. Survey, Paleontology Bull. 22, 77 p.

- 1955, Supposedly colpate pollen grains from the Jurassic: Geol. Mag., v. 92 , p. $471-474$.

1958, British Mesozoic microspores and pollen grains- $\mathbf{A}$ systematic and stratigraphic study: Palaeontographica, v. 103, Abt. B, no. 4-6, p. 75-179.

Deflandre, G., 1937, Microfossiles de Silex Crétacés, 2e pte-Flagellés incertae sedis; Hystrichosphaeridés; Sarcodjnés; Organismes divers: Annales de paléontologie, v. 26, p. 51-73.

- 1944, Microfossiles des calcaires siluriens de la Montagne Noire: Annales de paléontologie, v. 31, p. 41-75.

1946, Radiolaires et Hystrichosphaeridés du Carbonifère de la Montagne Noire: Acad. Sci. (Paris) Comptes rendus, v. 223, p. 515-517.

Deflandre, G. and Cookson, I., 1955, Fossil microplankton from Australian Late Mesozoic and Tertiary sediments: Aust. Jour. Marine and Freshwater Research, v. 6 , no. 2 , p. 242-313.

Delcourt, A., and Sprumont, G., 1955, Les spores et grains de pollen du Wealdien du Hainaut: Soc. belge de géologie, de paleontologie et d'hydrologie, Mém. n. s. in quarto, no. 5, p. 5-73.

Dorf, E., 1952, Critical analysis of Cretaceous stratigraphy and paleobotany of Atlantic Coastal Plain: Am. Assoc. Petroleum Geologists, v. 36, no. 11, p. 2161-2184.

Erdtman, G., 1954, On pollen grains and dinoflagellate cysts in the Firth of Gullmarn, S. W. Sweden: Botaniska Notiser, Särtryck no. 2, p. 103-111.

Faegri, K., and Iversen, J., 1950, Text-book of modern pollen analysis: E. Munksgaard, Copenhagen, $168 \mathrm{p}$.

Fritsch, F. E., 1956, The structure and reproduction of the algae, v. 1; Cambridge Univ. Press, $791 \mathrm{p}$.

Funkhouser, J. W., and Evitt, W. R., 1959, Preparation techniques for acid-insoluble microfossils, Micropaleontology, v. 5, no. 3, p. 369-375.

Groot, J. J., and Penny, J. S., 1960, Plant microfossils and age of nonmarine Cretaceous sediments of Maryland and Delaware: Micropaleontology, v. 6, no. 2, p. 225-236.

Kräusel, Richard, 1948, Die fossilen Koniferen-Holzer (Unter Ausschluss von Araucarioxylon Kraus): Palaeontographica, v. 89, Abt. B, p. 83-203.

Krutzsch, W., 1957, Sporen- und Pollengruppen aus der Oberkreide und dem Tertiär Mitteleuropas und ihre stratigraphische Verteilung: Zeitschr. angew. Geologie, no. 11-12, p. 509-548. 
Krutzsch, W., 1959, Einige Neue Formgattungen und -Arten von Sporen und Pollen aus der Mitteleuropäischen Oberkreide und dem Tertiär: Palaeontographica, v. 105 , Abt. B., p. 125-157.

McKee, E. D., Chronic, J., and Leopold, Estella B., 1959, Sedimentary belts in lagoon of Kapingamarangi Atoll: Am. Assoc. Petroleum Geologists Bull., v. 43 , no. 3 , p. $501-562$.

Monroe, W. H., 1947, Stratigraphy of outcropping Cretaceous beds of Southeastern States: Am. Assoc. Petroleum Geologists Bull., v. 31, no. 10, p. 1817-1824.

- 1955, Cores of pre-Selma Cretaceous rocks in the outcrop area in western Alabama: Gulf Coast Assoc. Geol. Socs. Trans., v. 5, p. 11-37.

Pflug, H. D., 1953, Zur Entstehung und Entwicklung des Angiospermiden Pollens in der Erdgeschichte: Palaeontographica, v. 95, Abt. B, no. 4-6, p. 60-171.

Potonié, R., 1931, Pollenformen der miocaenen Braunkohle: Gesell. Naturf. Freunde Berlin, Ber., no. 1-3, p. 24-28.

—_ 1934, Zur Mikrobotanik des eocaenen Humodils des Geiseltals: Preuss. Geol. Landesanst. Berlin, Arb. Inst. Palaeobot. u. Petrogr. Brennst., v. 4, p. 25-125.

1956, Synopsis der Gattungen der Sporae dispersae; 1. Teil-Sporites: Geol. Jahrb., Beihefte, v. 23, 103 p.

— 1958, Synopsis der Gattungen der Sporae dispersae; 2. Teil-Sporites (Nachträge), Saccites, Aletes, Praecolpates, Polyplicates, Monocolpates: Geol. Jahrb., Beihefte, v. 31, 114 p.

1960, Synopsis der Gattungen der Sporae dispersae, 3. Teil-Geol. Jahrb., Beihefte, Heft 39, 189 p.

Rouse, G. E., 1959, Plant microfossils from Kootenay coal-measures strata of British Columbia: Micropaleontology, v. 5, no. 3, p. 303-324.

Scott, R. A., 1960, Pollen of Ephedra from the Chinle formation (Upper Triassic) and the genus Equisetosporites: Micropaleontology, v. 6, no. 3, p. 271-276.

Scott, R. A., Barghoorn, E. S., and Leopold, Estella B., 1960, How old are the angiosperms?: Am. Jour. Sci., v. 258-A, p. 284-299.

Sharp, A. J., 1949, Distributión del Género Podocarpus en México: Soc. Botanica de México, Boletín no. 8, p. 25.

Stephenson, L. W., King, P. B., Monroe, W. H., and Imlay, R. W., 1942, Correlation of the outcropping Cretaceous formations of the Atlantic and Gulf Coastal Plain and Trans-Pecos Texas: Geol. Soc. America Bull., v. 53, p. 435-448.

Thiergart, Fr., 1953, Utber einige Sporen und Pollen der Perutzer Schichten (Böhmen): Palaeontographica, v. 95, Abt. B., no. 4-6, p. 53-59.

Thomson, P. W., and Pflug, H., 1953, Pollen und Sporen des Mitteleuropäischen Tertiärs: Palaeontographica, v. 94, Abt. B., nos. 1-4, p. 1-138.

Traverse, A. F., Jr., 1955, Pollen analysis of the Brandon lignite of Vermont: U.S. Bur. Mines Rept. Inv. 5151, 107 p.

Wetzel, O., 1933, Die in organischer Substanz erhaltenen Microfossilien des baltischen Kreide-Feuersteins: Palaeontographica, v. 78, Abt. B., p. 1-111.

Weyland, H., and Greifeld, G., 1953, Utber strukturbietende Blätter und pflanzliche Mikrofossilien aus den Untersenonen Tonen der Gegend von Quedlinburg: Palaeontographica, v. 95, Abt. B, no. 1-3, p. 30-52.

Weyland, H., and Krieger, W., 1953, Die Sporen und Pollen der Aachener Kreide und ihre Bedeutung für die Charakterisierung des Mittleren Senons: Palaeontographica, v. 95, Abt. B, no. 1-3, p. 6-29.

Wilson, L. R., and Hoffmeister, W. S., 1952, Small Foraminifera: Micropaleontologist, v. 6, no. 2, p. 26-28. 



\section{PLATE 3}

[All figures magnified $500 \times$ ]

Figures 1, 2. Cicatricosisporites brevilaesuratus Couper 1953. Slide D1457-1(2) at $100 \times 7.4$.

3-7. Cicatricosisporites dorogensis R. Potoni ${ }^{\circ} \&$ Gelletich, 1933.

3 , 4. Slide D1111-9(5) at $128.8 \times 6.9$.

5, 6. Slide D1111-9(5) at $104.1 \times 8.3$.

7. Slide D1111-9(5) at $116.5 \times 8$.

8, 9. Cicatricosisporites sp.? Slide D1457-1(3) at $128.8 \times 10.5$.

10-13. Cingulatisporites problematicus Couper 1958.

10, 11. Slide D1457-1(5) at $113.9 \times 11$.

12, 13. Slide D1457-1(2) at $105 \times 9.9$.

14, 15. Taurocusporites reduncus (Bolkhovitina) Stover 1962. Slide D1457-1(3) at $129.3 \times 20.8$.

16, 18-19, 27. 16. Slide D1109-10(5) at $127.8 \times 23.1$.

18 , 19. Slide D1109-10(4) at $105.8 \times 5.1$.

27. Slide D1109-10(5) at $122 \times 23$.

Trilites sp.

17. Trilites veriucatus Couper 1953. Slide D1457-1(3) at $109.9 \times 17.1$

20-25. Triplanosporites sinuosis Pflug \& Thomson 1953.

20. Slide D1109-7(2) at $115.2 \times 19.2$.

21. Slide D1111-9(5) at $123.5 \times 14.5$.

22, 23. Slide D1111-9(5) at $121.7 \times 12.8$.

24, 25. Slide D1109-4(2) at $123 \times 9.8$.

26. Concavisporites rugulatus Pflug 1953. Slide D1109-10(4) at $132 \times 4.3$.

28-30. Leiotriletes ef. L. subtilis Bolkhovitina 1953. Slide D1109-4(2) at $122.7 \times 12$.

31. Sporites arcifer Thiergart 1948. Slide D1109-10(1) at $119.3 \times 11.9$

32-34. Cyathidites mesozoicus (Thiergart) R. Potoni ${ }^{\circ} 1956$.

32, 33. Slide D1111-9(5) at $133.5 \times 13.5$.

34. Slide D1109-10(5) at $109.9 \times 23$.

35. Concavisporites ef. C. punctatus Delcourt \& Sprumont 1955. Slide D1109-4(5) at $121.4 \times 16$.

36. Torisporis intrastructurius Krutzsch 1959. Slide D1457-1(2) at $114.9 \times 18.1$.

37, 38. Deltoidospora cf. D. hallii Miner 1935. Slide D1109-10(4) at $136.1 \times 12.3$.

39. Monolites major Cookson 1947. Slide D1111-9(5) at $112.4 \times 4.9$. 

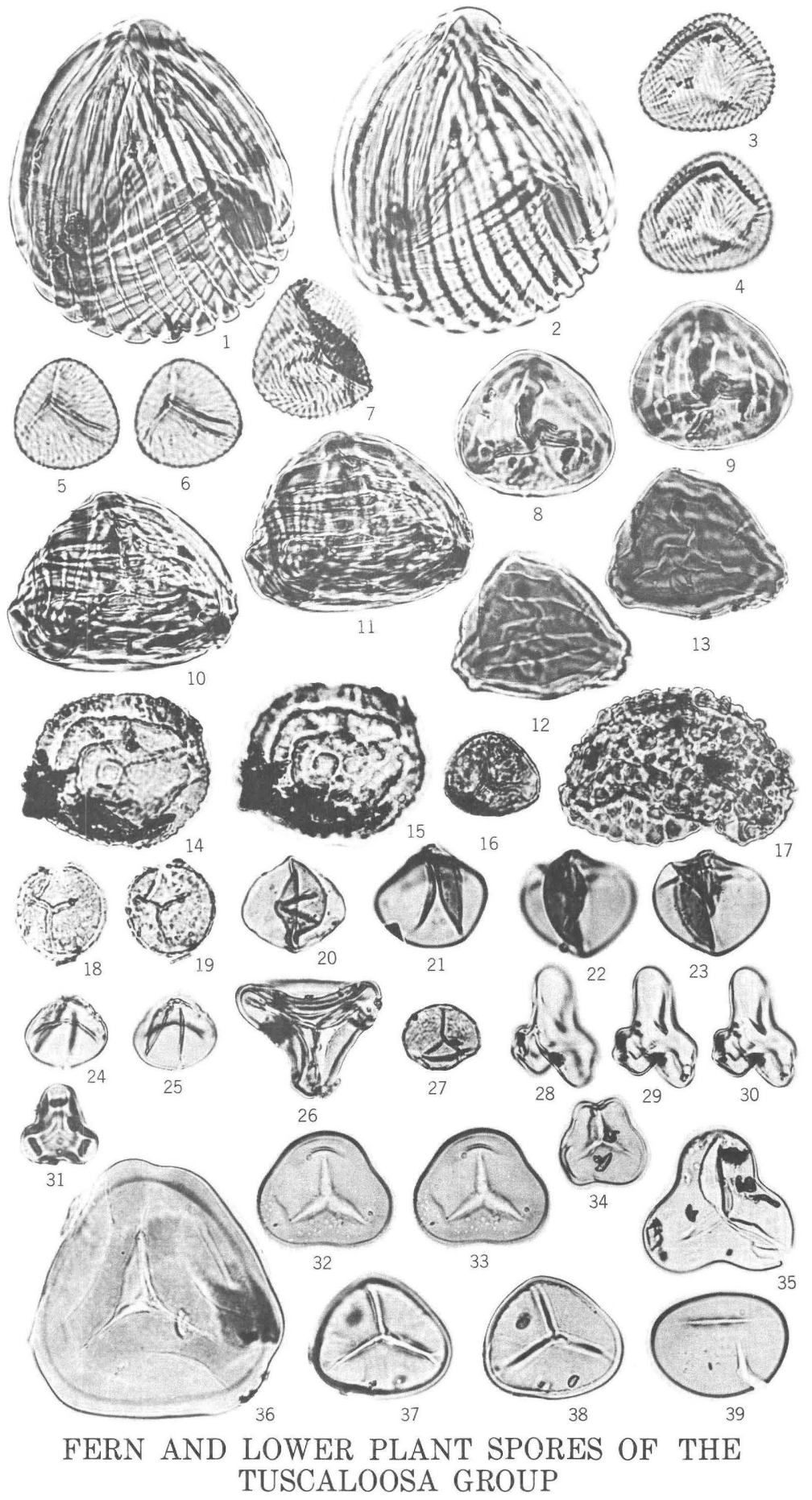


\section{PLA'TE 4}

\section{[All figures magnified $500 \times$ ]}

Figures 1. Sequoiapollenites polyformosus Thiergart 1938. Slide D1111-9 (5) at $133.5 \times 8.2$.

2. Inaperturopollenites Pflug 1953. Slide D 1109-4(4) at $130.2 \times 9.1$.

3. Cingulatisporites of. C. scabratus Couper 1958. Slide D1111-9 (5) at $120.7 \times 4.7$.

4-7. Pityosporites microalatus (R. Potonié) Thomson \& Pflug 1953. 4. Slide D1109-10(4) at $122.5 \times 12.2$.

5, 6, 7. Slide D1109-10(4) at $132.1 \times 16.5$.

8-10. Pinuspollenites labdacus (R. Potonié) Raatz 1937. Slide D1109-7(4) at $109.2 \times 10.1$.

11-13. Podocarpidites cf. P. major Couper 1953. Slide D1109-10(4) at $120.8 \times 4$.

14-16. Podocarpidites cf. P. biformis Rouse. Slide D1109-10(4) at $105.8 \times 5.1$.

17-18. Cycadopites cf. C. follicularis Wilson \& Webster 1946. Slide D1111-9(5) at $124.4 \times 6.7$.

19. Gynkaletes cf. G. retrfloexus (Luber) Luber 1956. Slide D1109$10(4)$ at $130.5 \times 19.3$.

20-22. 'Gynkaletes Luber 1955. Slide D1109-10(5) at $129.71 \times 3$.

23, 24. Perinopollenites cf. P. elatoides Couper 1958. Slide D109-4(2) at $122.2 \times 18$. 

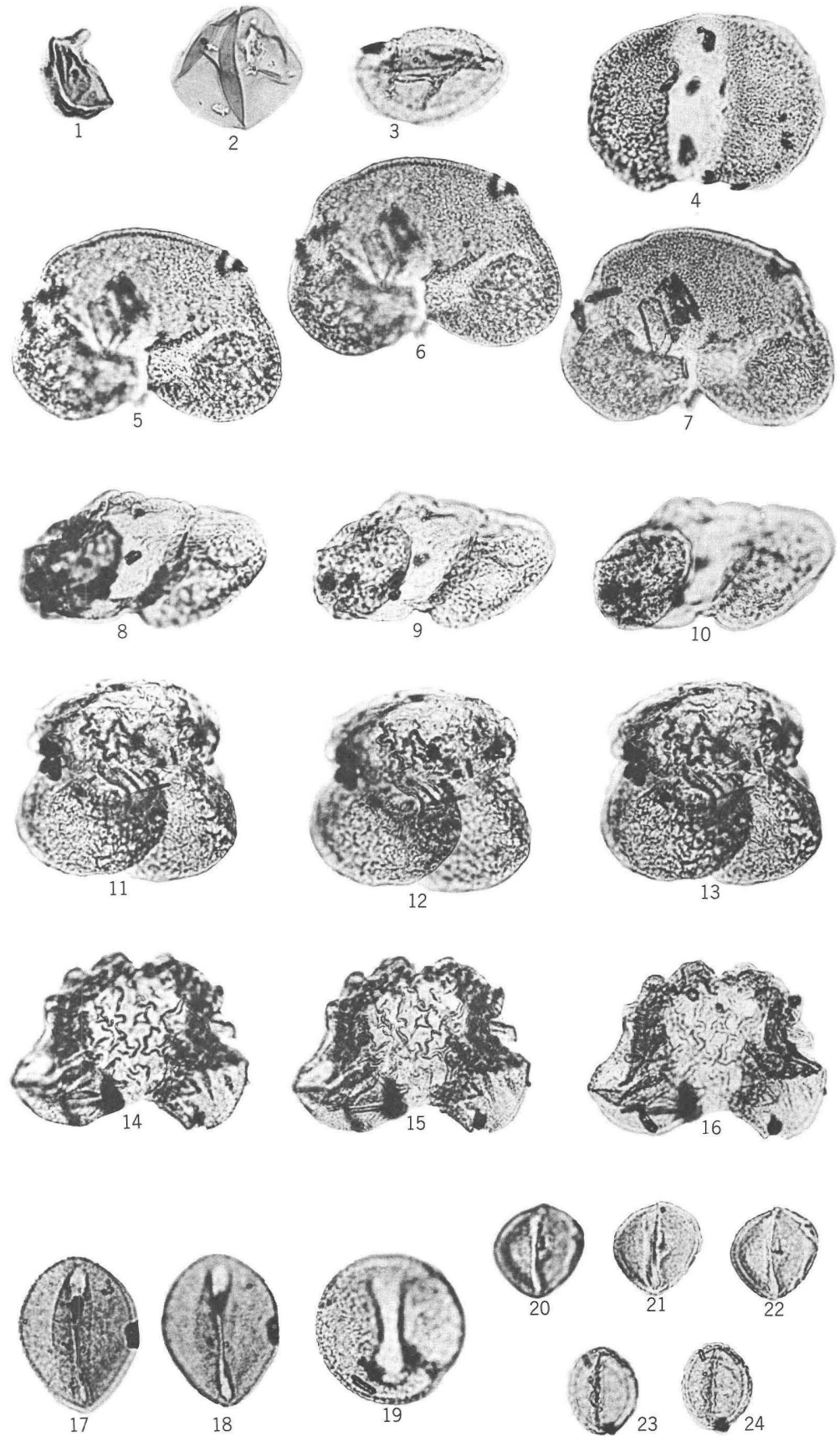

GYMNOSPERM POLLEN OF THE TUSCALOOSA GROUP 


\section{PLATE 5}

[All figures magnified $500 \times$ ]

Figures 1-5. "Tricolpopollenites" Thomson \& Pflug 1953 (unnamed species).

1, 2. Slide $1109-4(3)$ at $114.8 \times 20$.

3. Slide D1111-9(5) at $111.4 \times 9.2$.

4, 5. Slide D1109-10(5) at $125.8 \times 2.9$.

6, 7. Pollenites quisqualis R. Potonié 1934.

6. Slide D1109-10(5) at $108.9 \times 23$.

7. Slide D1111-9(5) at $126.2 \times 9.3$.

8, 9, 18, 19. Pollenites megagertrudae R. Potonié 1931.

8, 9. Slide D1109-7(3) at $117.9 \times 4.8$.

18, 19. Slide D1109-4(3) at $125.9 \times 20$.

10, 11. Quercoidites henrici (R. Potonié 1931) R. Potonié, Thomson \& Thiergart 1950. Slide D1109-7(4) at $116.8 \times 10.2$.

12, 13. Pollenites grossularius R. Potonié 1934. Slide D1109-10(5) at $104.2 \times 11.7$.

14, 15. Platanoidites Potonié, Thomson \& Thiergart, 1950. Slide D1111-9(5) at $130.5 \times 4.9$.

16. "Tricolpopollenites ef. T. retiformis" Thomson \& Pflug 1953. Slide D1111-9(5) at $127 \times 14.5$.

17. "Tricolpopollenites retiformis" Thomson \& Pflug 1953. Slide D1111-9(5) at $108.8 \times 9.1$.

20, 21. Salix discoloripites Wodehouse 1933. Slide D1111-9(5) at $111.5 \times 9.4$.

22. ef. Paliurus rhamnoides Bolkhovitina 1953. Slide D1109-7 (4) at $129 \times 12.4$.

23, 24. Triorites ef. T. edwardsii Cookson \& Pike 1954. Slide D1109-7(4) at $124 \times 6.2$.

25, 26. T. edwardsii Cookson \& Pike 1954. Slide D1109-4(3) at $122.4 \times 20$.

27, 28. Basopollis orthobasalis (Pflug) Pflug 1953. Slide D1109$4(2)$ at $102.2 \times 11.8$.

29-33. Sporopollis Pflug 1953.

29, 30. Slide D1109-4(3) at $103.3 \times 17.8$.

31, 32, 33. Slide D1109-4(3) at $138.9 \times 18$.

34-38. Sporopollis pseudosporites Pflug 1953.

34, 35, 36. Slide D1109-7(4) at $131.5 \times 7.5$.

37, 38. Slide D1109-10(5) at $109.9 \times 20$. 
ए)

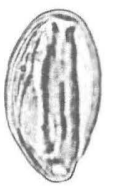

10

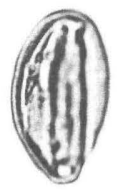

11

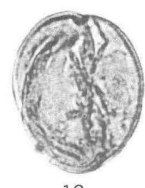

12

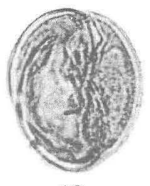

13

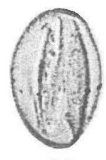

14

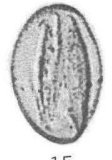

15
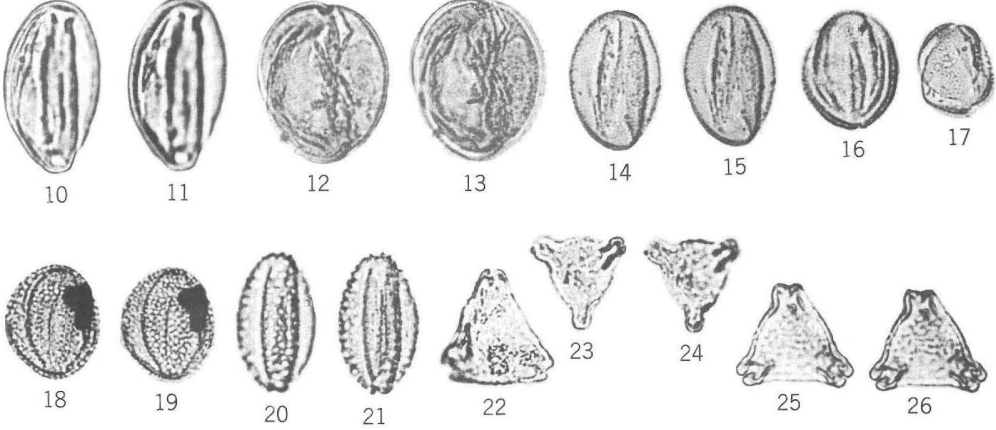

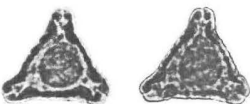

27

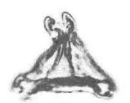

29
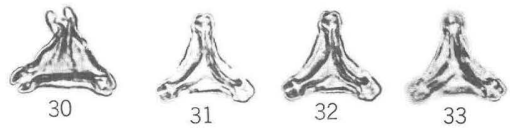

है।
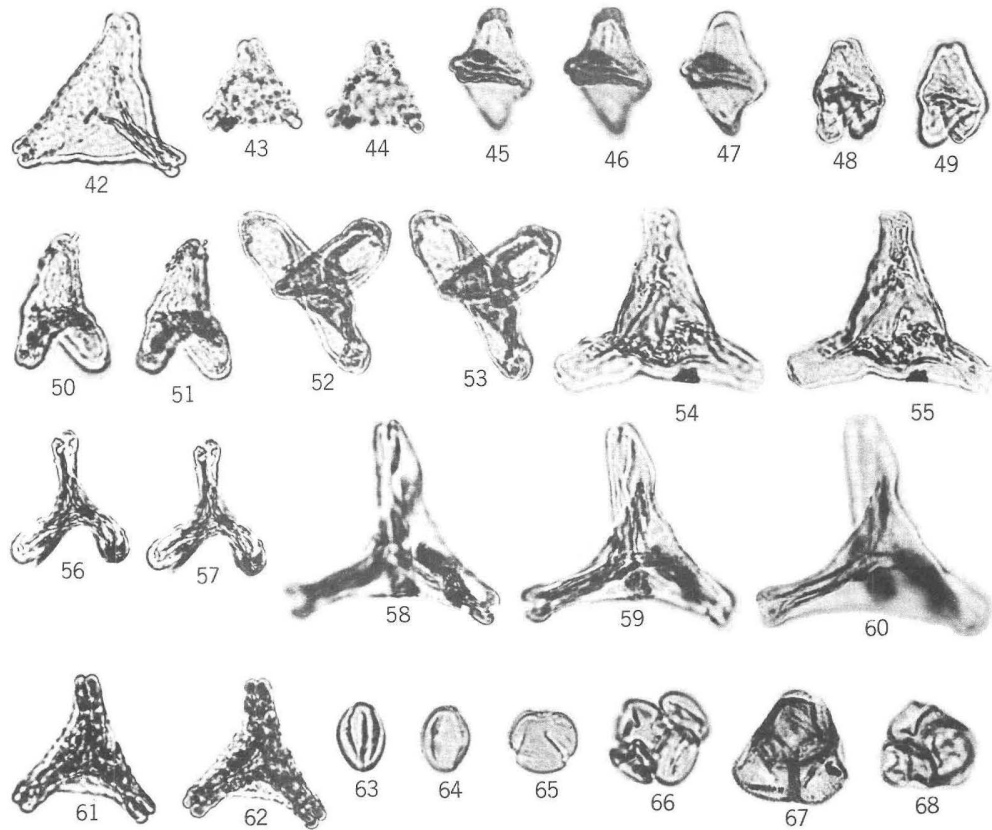

DICOTYLEDONOUS POLLEN OF THE TUSCALOOSA GROUP 


\section{PLATE 5-Continued}

[All figures magnified $500 \times$ ]

Figures 39, 40, 41. Sporopollis cf. S. pseudosporites Pflug 1953. Slide D1109-7(3) at $111.2 \times 17.1$.

42. Complexipollis praeatumescens Krutzsch 1959. Slide D1457-1(4) at $117.2 \times 16.9$.

43, 44. Triorites ef. T. edwardsii Cookson \& Pike 1954. Slide D1109-7(2) at $110 \times 13.4$.

45-47. Latipollis latis Krutzsch 1959. Slide D1109-7(4) at 114.4 $\times 3.8$.

48, 49. Latipollis normis Krutzsch 1959. Slide D1109-7(3) at 115.1 $\times 8$.

50-53. Latipollis ef. L. latis Krutzsch 1959.

50, 51. Slide D1457-1(5) at $113 \times 13$.

52 , 53. Slide D1457-1(2) at $106.4 \times 5$.

54-60. ?Latipollis Krutzsch 1959. Polar view.

54, 55. Slide D1109-7(4) at $128.8 \times 22$.

56, 57. Slide D1457-1(3) at $115.2 \times 19$.

58-60. Slide D1109-7(4) at $136 \times 18.3$.

61, 62. Nudopollis ornatus (Pflug) Pflug 1953. Slide D1457-1(2) at $110.5 \times 5.3$.

63, 64. "Tricolporopollenites distinctus" Groot \& Penny 1960.

63. Slide D1111-9(5) at $105.1 \times 13$.

64. Slide D1111-9(5) at $123.9 \times 4.9$.

65. "Tricolpopollenites parvulus" Groot \& Penny 1960. Slide D1111-9(5) at $119.4 \times 4.7$.

66. Tricolpate pollen undetermined. Slide D1111-9(5) at 103 $\times 8.5$.

67, 68. Dicotetradites cf. D. clavatus Couper 1953.

67. Slide D1111-9(5) at $104.9 \times 9.6$.

68. Slide D1111-9(5) at $103.9 \times 9.6$. 



\section{PLA'T'E 6}

[All figures magnified $500 \times$ ]

Figures 1, 2. Plicatella trichacantha Malawkina 1949. Slide D1456-4(3) at $138.2 \times 20$.

3, 4. Cicatricosisporites sp. R. Potonié \& Gelletich 1933. Slide D1456-4(3) at $102.4 \times 12$.

5. cf. Schizaeoisporites sp. R. Potonié 1951. Slide D1110-1(3) at $129.5 \times 7.8$.

6, 7. Sporites arcifer Thiergart 1948. Slide D1110-2(5) at $126.4 \times$ 22.9 .

8. Cingulatisporites cf. C. scabratus Couper 1958. Slide D1456-4(3) at $122.1 \times 8.4$.

9, 10. ef. Rugulatisporites Thomson \& Pflug 1953. Slide D1110-2(5) at $127.1 \times 22.8$.

11, 12. Densoisporites perinatus Couper 1948. Slide D1110-3(3) at $117.2 \times 5.1$.

13-15. Deltoidospora hallii Miner 1935.

13. Slide D1456-4(1) at $129.5 \times 8.9$.

14, 15. Slide D1110-1(5) at $113.9 \times 10.8$.

16, 17. Hymenozonotriletes reticulatus Bolkhovitina 1953. Slide D1456$4(5)$ at $101.5 \times 19$.

18. Corrugatisporites arcuatus Weyland \& Greifeld 1953. Slide D1456-4(5) at $106.5 \times 22.8$.

19. Cingulatisporites dubius Couper 1958. Slide D1456-4(3) at 119 $\times 17.9$.

20. Araucariaceae? Slide D1456-4(1) at $126.9 \times 18$.

21, 22. Spores undetermined.

21. Slide D1456-5(1) at $127.2 \times 10.3$

22. Slide D1456-4(5) at $114.8 \times 23$.

23, 24. Ephedra sp. Tournefort ex Linnaeus 1737. Slide D1110-2(5) at $122.1 \times 14.7$.

25, 26. Inaperturopollenites dubius (R. Potonié \& Venitz) Thomson \& Pflug 1953.

25. Slide D1456-4(3) at $134.3 \times 17.2$.

26. Slide D1456-4(3) at $131.2 \times 11$.

27, 28. Taxodiaepollenites hiatus (R. Potonié) Thiergart 1940.

27. Slide D1110-3(5) at $123.9 \times 22.1$.

28. Slide D1456-4(3) at $130.5 \times 8.9$.

29. Araucariacites australis Cookson 1947. Slide D1456-4(3) at 123 $\times 19$.

30-32. Classopollis classoides Pflug 1953. Slide D1456-5(1) at $123.5 \times$ 14.

33-34. Caytonipollenites pallidus (Reissinger) Couper 1958. Slide D1110-1(3) at $131.7 \times 5.2$. 

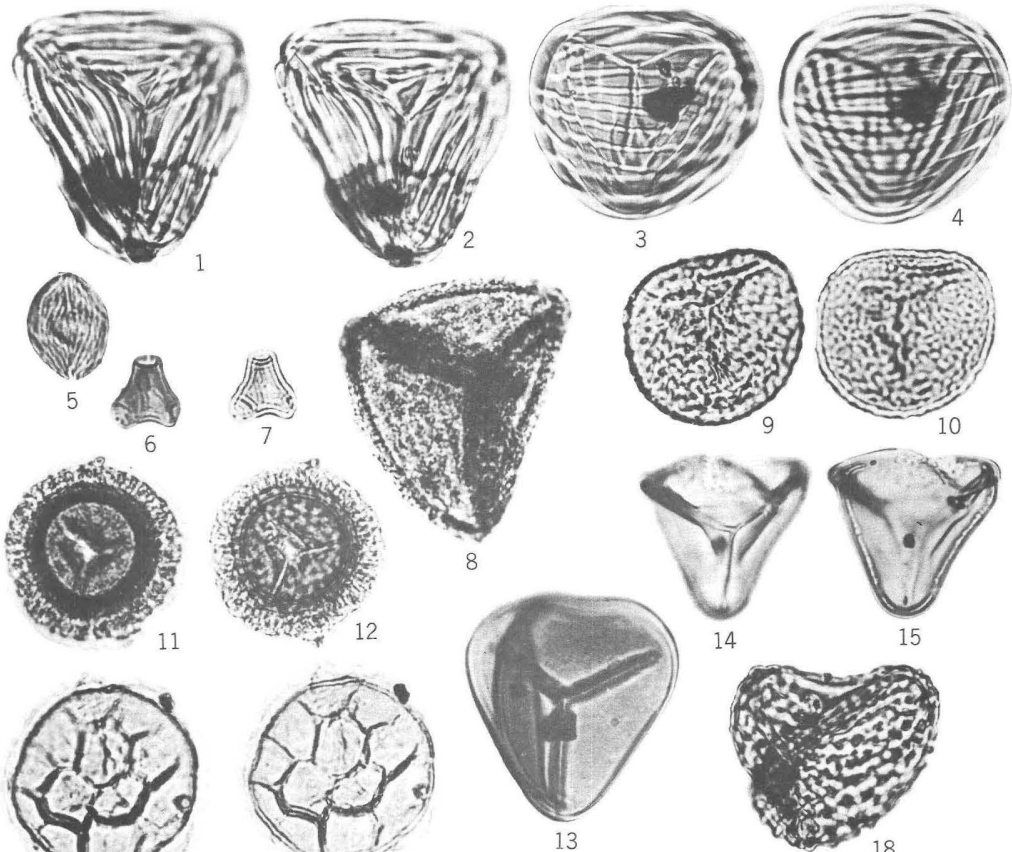

14

15
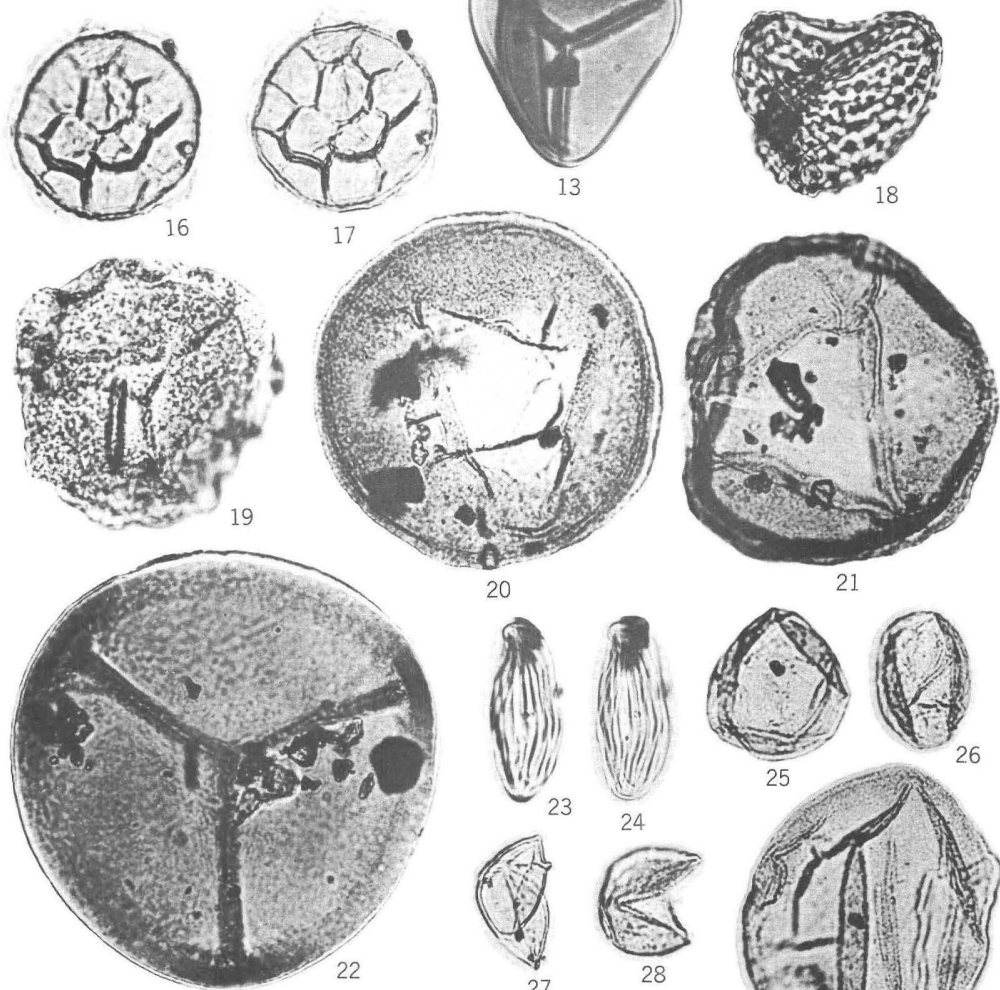

20
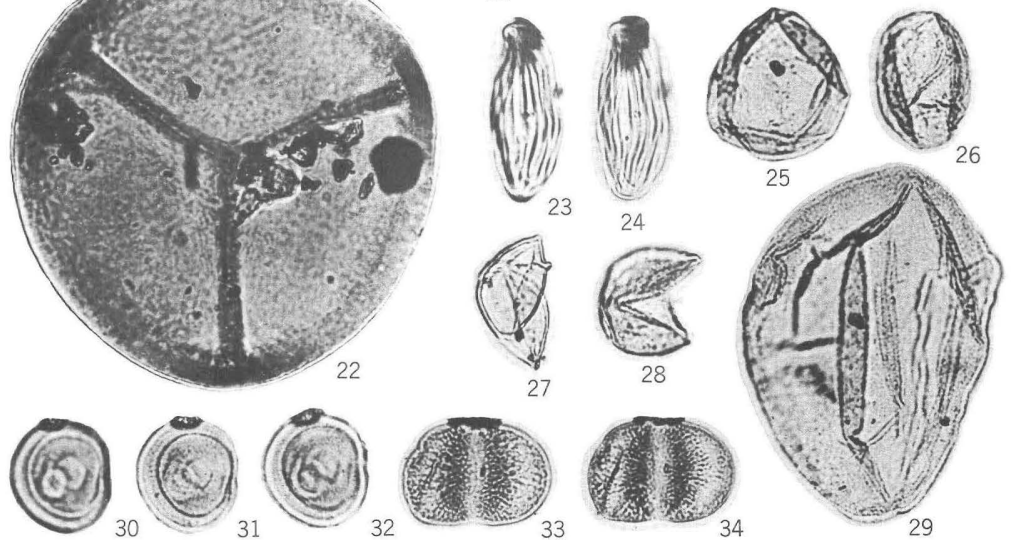

SPORES, GYMNOSPERM POLLEN AND PTERIDOSPERM POLLEN OF THE MCSHAN AND EUTAW FORMATIONS 


\section{PLA'TE 7}

[All figures magnified at $500 \times$ except figure 7]

Figures 1, 2. Dacrycarpites australiensis Cookson \& Pike 1953. Slide D1456$4(3)$ at $141.1 \times 3.3$.

3. Parvisaccites radiatus Couper 1958. Slide D1456-4(3) at $119.2 \times 13.4$.

4-6. Podocarpidites cf. P. major Couper 1953. Slide D1110-3(5) ta $113.6 \times 11.8$.

7. cf. Podocarpus (L'Heritier) Persoon 1807. $(\times 375)$. Slide D1456-6(1) at $123.3 \times 11.9$.

8-13. Podocarpidites cf. P. biformis Rouse 1957.

8, 9. Slide D1110-1(3) at $124.2 \times 9.9$.

10, 11. Slide D1456-4(3) at $141.2 \times 10.2$.

12 , 13. Slide D1110-1(6) at $105.3 \times 1.8$.

14-15. Abietineaepollenites microreticulatus Groot \& Penny 1960. Slide D1110-1(3) at $134.9 \times 9.2$.

16-18. Liliacidites intermedius Couper 1953. Slide D1110-2(6) at $110.1 \times 4.4$ 

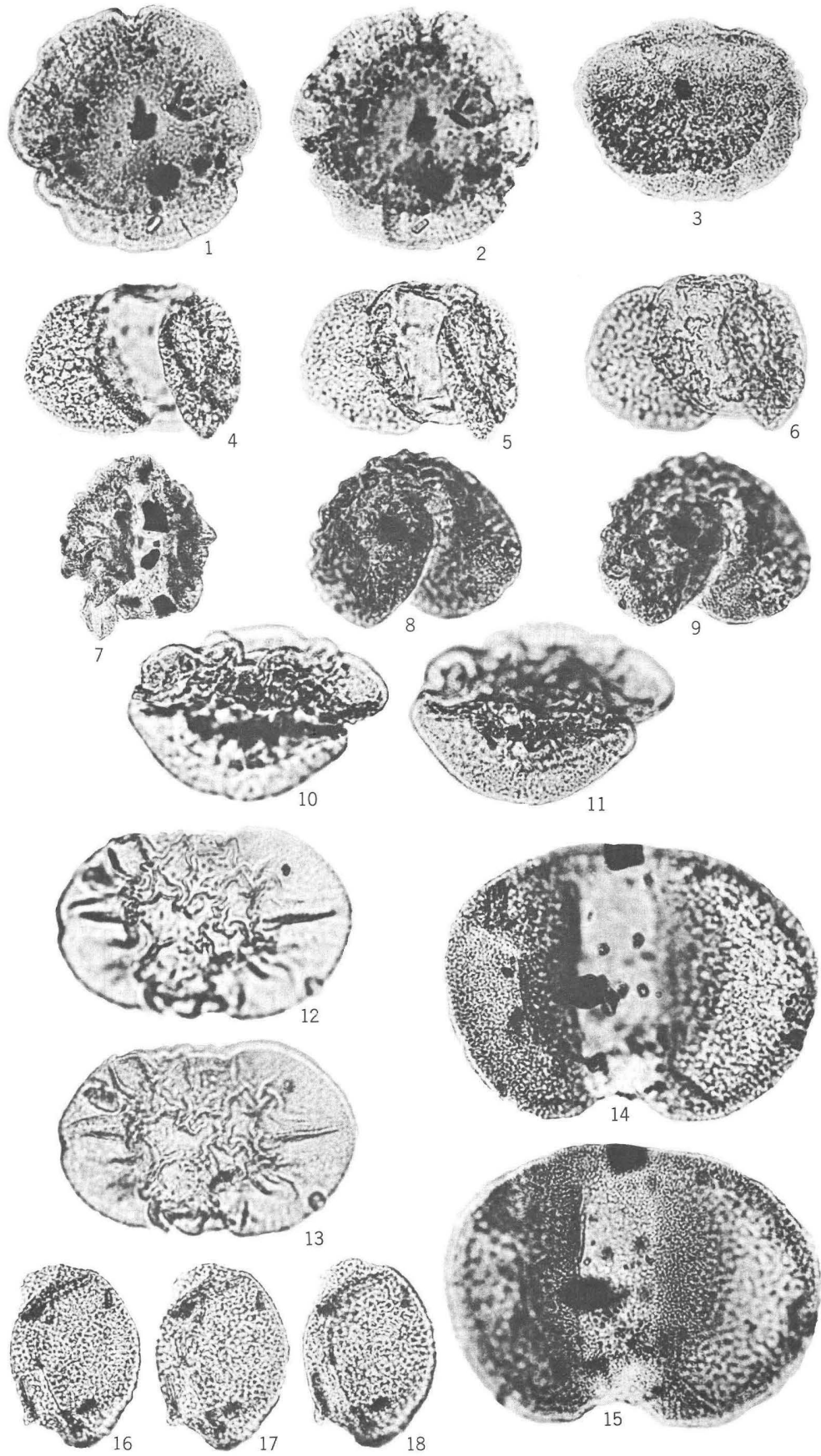

GYMNOSPERM AND MONOCOTYLEDONOUS POLLEN OF THE MCSHAN AND EUTAW FORMATIONS 


\section{PLATE 8}

[All figures magnified $500 \times$ ]

Figure 1. "Tricolpopollenites ef. T. retiformis" Thomson \& Pflug 1953. Slide D1110-1(6) at $132.1 \times 9.8$.

2, 3. Platanoidites gertrudae ( $\mathrm{R}$. Potonié 1931) R. Potonié, Thomson \& Thiergart, 1950. Slide D1110-1(6) at $117.7 \times 12$.

4, 5. Quercoidites microhenrici (R. Potonié 1931) R. Potonié, Thomson \& Thiergart 1950. Slide D1456-6(2) at $139.2 \times 9$.

6, 7. Quercoidites microhenrici subsp. intragranulatus Thomson $\&$ Pflug 1953. Slide D1456-4(1) at $123 \times 9.8$.

8. "Tricolpopollenites retiformis" Thomson \& Pflug 1953. Slide D1110-1(3) at $130.8 \times 4.1$.

9-13. Triatriopollenites rurensis Pflug \& Thomson 1953.

9. Slide D1456-4(7) at $128.3 \times 14.1$.

10. Slide D1110-1(6) at $128.5 \times 20.2$.

11. Slide D1456-4(3) at $136.3 \times 12.4$.

12, 13. Slide D1110-1(4) at $130 \times 10$.

14, 15. Triatriopollenites ef. T. concavus Thomson \& Pflug 1953.

14. Slide D1110-3(4) at $106.4 \times 6.4$.

15. Slide D1110-3(4) at $131.6 \times 16.1$.

16, 17. ef. Minorpollis minimus Krutzsch 1959. Slide D1456$4(1)$ at $123.5 \times 10.7$.

18-20. Trivestibulopollenites betuloides Thomson \& Pflug 1953. Slide D1110-3(5) at $131 \times 2.8$.

21-23. Sporopollis Pflug 1953.

21, 22. Slide D1456-4(3) at $131.3 \times 8$.

23. Slide D1456-4(5) at $137 \times 5$.

24, 25. cf. Paliurus rhamnoides Bolkhovitina 1953. Slide D1110$2(5)$ at $103.4 \times 16.2$.

26-28. Conclavipollis anulopyramis Pflug 1953. Slide D1456$5(1)$ at $110.8 \times 17$.

29, 30. Latipollis subtils Krutzsch 1959. Slide D1110-3(3) at $138.7 \times 9.1$.

31-34. Latipollis Krutzsch 1959.

31. Slide D1110-3(4) at $114.5 \times 6.4$.

32. Slide D1456-4(3) at $136.2 \times 11.1$.

33 , 34. Slide D1456-4(3) at $120 \times 10$.

35, 36. Triatriopollenites Pflug 1953. Slide D1456-6(2) at $128 \times$ 3.6 . 


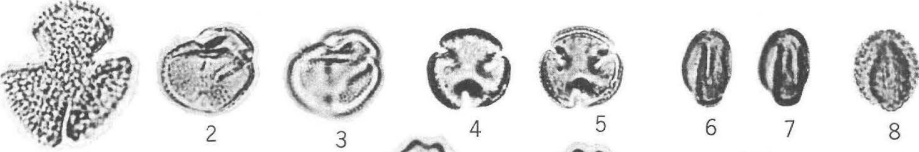
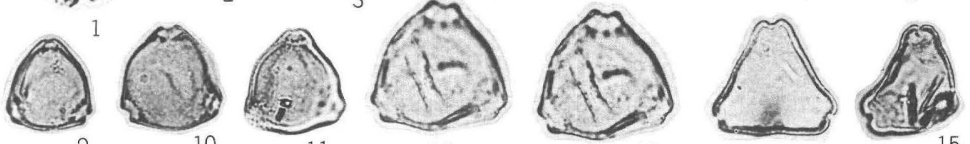

32
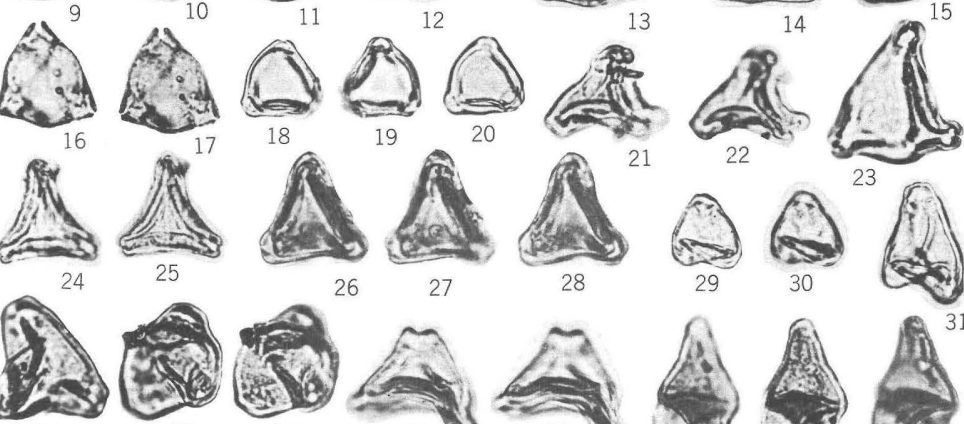

(1)

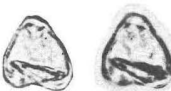

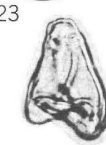

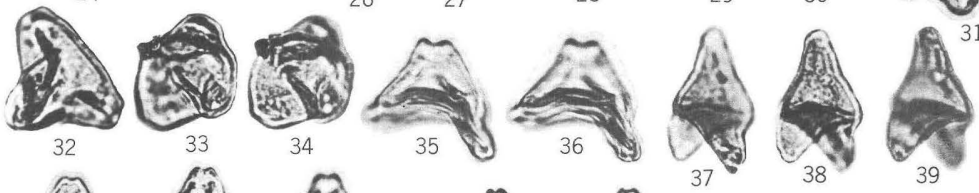

$\Delta A$
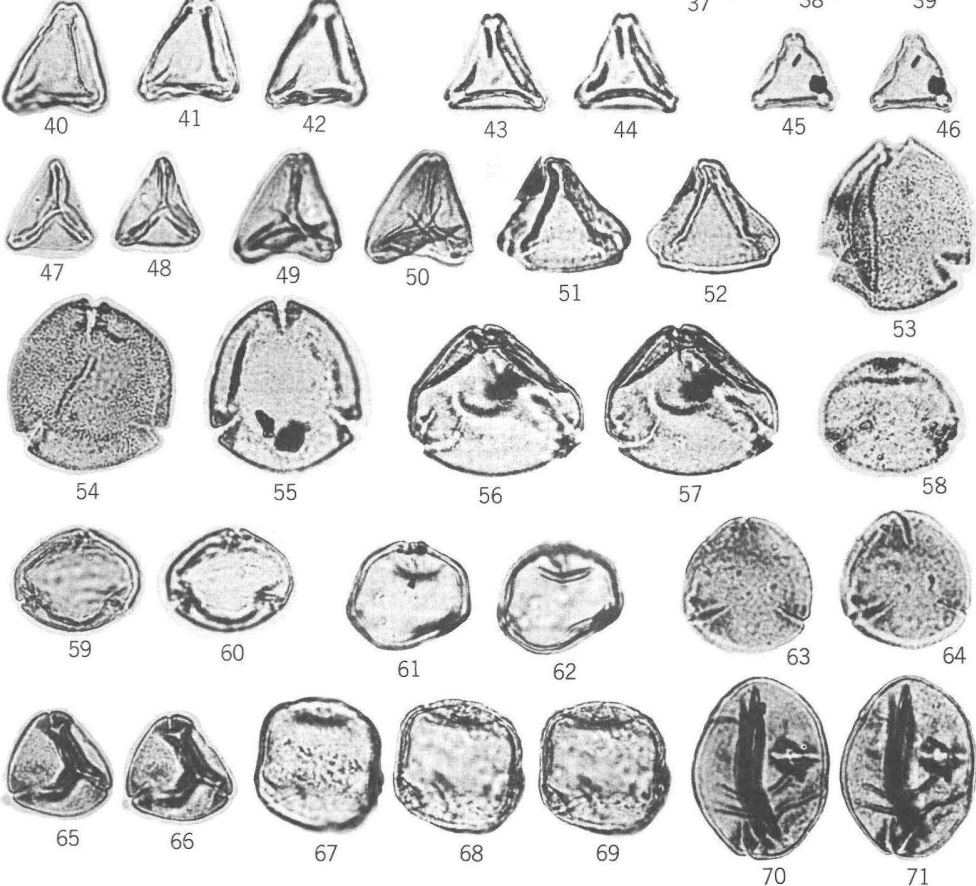

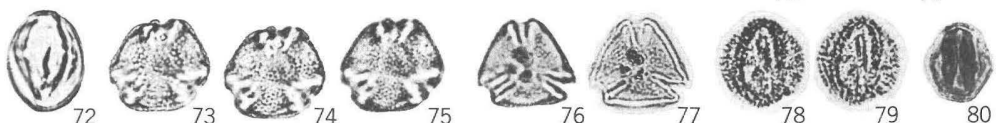

DICOTYLEDONOUS POLLEN OF THE MCSHAN AND EUTAW FORMATIONS 


\section{PLATE 8-Continued}

Figure 37, 38, 39. Latipollis latis Krutzsch 1959. Slide D1456-4(1) at $126 \times 9.4$.

40-46. Sporopollis pseudosporites Pflug 1953.

40, 41, 42. Slide D1110-3(4) at $103 \times 4.1$.

43, 44. Slide D1110-3(5) at $107.8 \times 9.5$.

45, 46. Slide D1110-3(5) at $134.5 \times 22$.

47, 48. Sporopollis laqueaeformis Weyland \& Greifeld 1953.

Slide D1110-3(4) at $127.4 \times 4.0$.

49, 50. Sporopollis Pflug 1953. Slide D1456-4(1) at $110.8 \times 6.2$.

51,52. Tenerina tenera Krutzsch 1957. Slide D1110-1(4) at $117.2 \times 9.4$.

53-58. Porocolpopollenites Thomson \& Pflug 1953 (some unnamed species).

53. Slide D1456-4(3) at $124.3 \times 12.2$.

54. Slide D1110-1(6) at $127 \times 17.9$.

55. Slide D1456-4(8) at $101.4 \times 16.8$.

56,57 . Slide D1456-4(5) at $98.2 \times 20.2$.

58. Slide D1456-4(8) at $116.3 \times 11.9$.

59,60. Porocolpopollenites orbiformis Thomson \& Pflug 1953. Slide D1110-2(5) at $111.3 \times 13$.

61-64, 67-71. Porocolpopollenites Thomson \& Pflug 1953 (some unnamed species).

61, 62. Slide D1456-5(1) at $126.5 \times 16$.

63,64 . Slide D1110-1(3) at $117.4 \times 19.9$.

$67,68,69$. Slide D1110-3(4) at $104 \times 15.7$.

70, 71. Slide D1456-4(1) at $129.8 \times 6.3$.

65, 66. Symplocoipollenites vestibulum (R. Potonié 1931) R. Potonié 1951. Slide D1456-4(7) at $121.5 \times 14.3$.

72. "Tricolporopollenites ef. T. eschweilerensis" Thomson \& Pflug 1953. Slide D1110-2(3) at $128.6 \times 13.7$.

73-77. Pollenites kruschi (R. Potonié) "asp. pseudolaesus" (R. Potonié) Thomson \& Pflug 1953.

73, 74, 75. Slide D1456-4(5) at $133.9 \times 18.8$.

76, 77. Slide D1110-2(5) at $137.8 \times 20.1$.

78, 79. "Tricolporpollenites"Thomson \& Pflug 1953 (unnamed species with bacculae). Slide D1110-1(5) at $111.3 \times$ 3.3 .

80. "Tricolporopollenites" Thomson \& Pflug 1953 (unnamed species). Slide D1110-1(3) at $134.4 \times 9.9$. 



\section{PLATE 9}

[All figures magnified 500 $\times$ except figure 4]

Figure 1. Fungal teleutospore of the Basidiomycetae. Slide D1456-4(5) at $128.5 \times 7$.

2, 3. cf. Tetraporina Naumova 1950. Slide D1456-4(3) at $131.1 \times 12.2$.

4. Microforaminifer $(\times 250)$. Slide D1110-1(3) at $131.8 \times 6.0$.

5. Schizosporis reticulatus Cookson \& Dettmann 1959. Slide D1456-5 (1) at $122.2 \times 19.9$.

6. Pterospermopsis ginginensis Deflandre \& Cookson 1955. Slide D1456-4(3) at $132.5 \times 5.2$.

7. Hystrichosphaeridium cf. H. multifurcatum Deflandre 1937. Slide D1110-1(3) at $125.3 \times 5.4$.

8. Micrhystridium pavimentum Deflandre 1945. Slide D1456-4(3) at $129 \times 22.9$.

9. Sporites echinosporus R. Potonié 1934. Slide D1456-6(4) at $129 \times$ 21.

10. Micrhystridium piliferum Deflandre 1936. Slide D1110-2(5) at $108 \times 7.3$.

11. Hystrichosphaeridium truncigerum Deflandre 1937. Slide D1110-2 (5) at $106.2 \times 14$.

12. Hystrichosphaeridium xanthiopyxides var. parvispinum Deflandre 1937. Slide D1110-1(6) at $125.1 \times 20.2$.

13. Hystrichosphaeridium pulcherrimum Deflandre \& Cookson 1955. Slide D1110-1(6) at $107 \times 11.6$.

14. Paleohystrichosphora infusorioides Deflandre 1955. Slide D1110-3 (1) at $129.9 \times 18.9$.

15, 16. Deflandrea bakeri forma pellucida Deflandre \& Cookson 1955.

15. Slide D1110-1(3) at $132.2 \times 16.4$.

16. Slide D1110-1(3) at $134 \times 9$. 

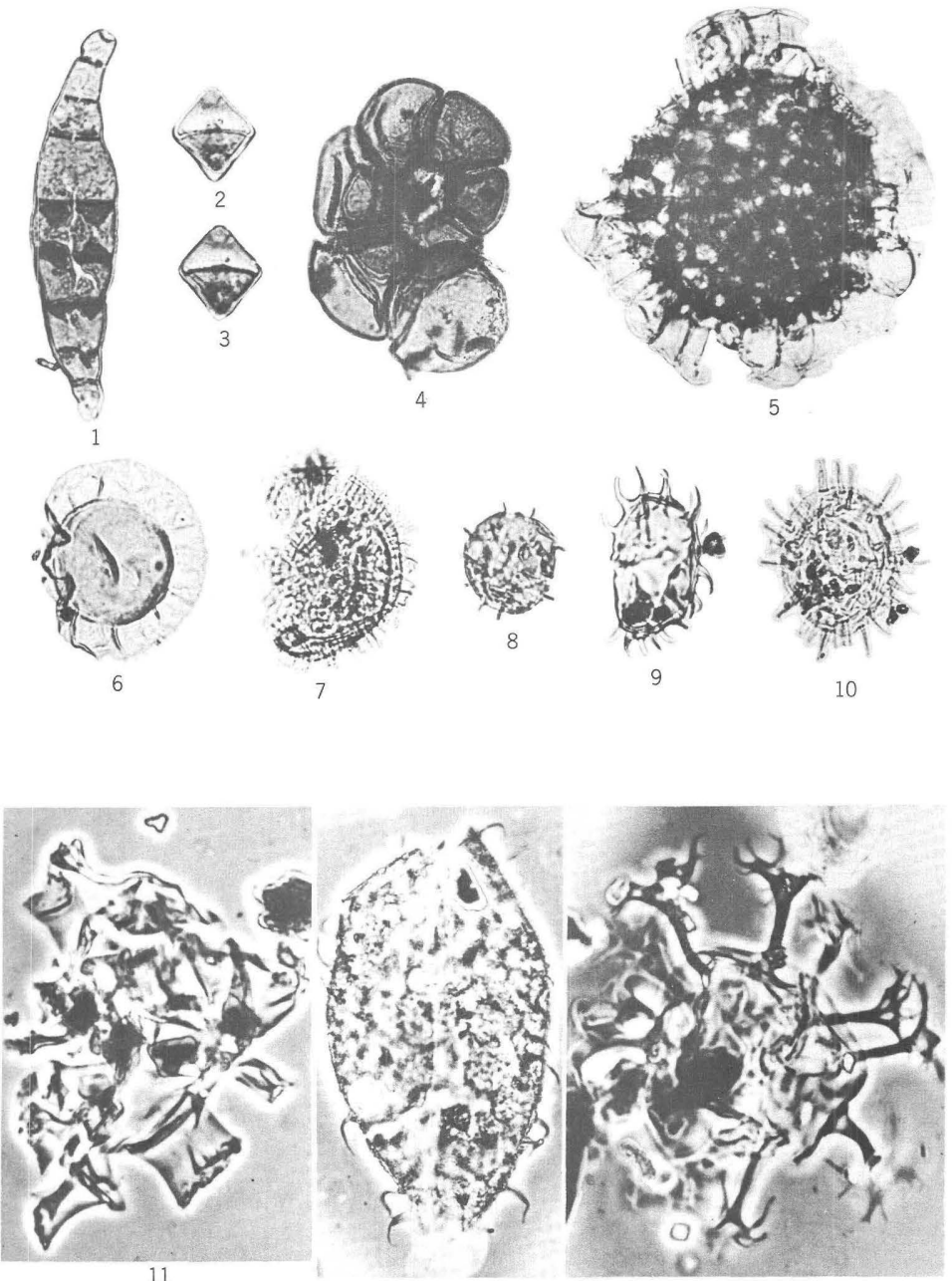

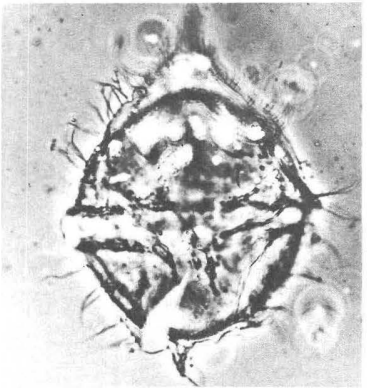

14

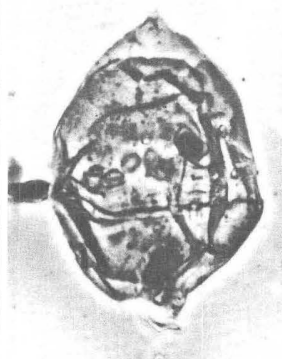

15

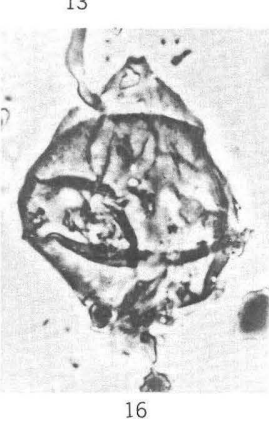

MICROFORAMINIFERS, DINOFLAGELLATE ALGAE AND HYSTRICHOSPHAERIDEAE OF THE MCSHAN AND EUTAW FORMATIONS 
